\title{
A new computer program TecDIA for multidimensional tectonic discrimination of intermediate and acid magmas and its application to the Bohemian Massif, Czech Republic
}

\author{
Surendra P. VERMA ${ }^{1, *}{ }^{,}$, Rene CRUZ-HUICOCHEA², Lorena DÍAZ-GONZÁLEZ3 ${ }^{3}$, Sanjeet K. \\ VERMA $^{4,5}$
}
${ }^{1}$ Instituto de Energías Renovables, Universidad Nacional Autónoma de México, Privada Xochicalco s/n, Col. Centro, Temixco, Mor., 62580, Mexico;spv@ier.unam.mx
2 Posgrado en Ingeniería (Energía), Instituto de Energías Renovables, Universidad Nacional Autónoma de México, Privada Xochicalco s/n, Col. Centro, Temixco, Mor., 62580, Mexico
3 Centro de Investigación en Ciencias, Instituto de Investigación en Ciencias Básicas y Aplicadas, Universidad Autónoma del Estado de Morelos, Cuernavaca, Mor. 62209, Mexico
${ }^{4}$ Department of Geology and Natural Resources, Institute of Geosciences, PO Box 6152, University of Campinas-UNICAMP, 13083-970, Campinas, SP, Brazil
${ }_{5}^{5}$ Present address: División de Geociencias Aplicadas, Instituto Potosino de Investigación Científica y Tecnológica, Camino a la Presa San José 2055, San Luis Potosi 78216, Mexico; sanjeet.verma@ipicyt.edu.mx
* Corresponding author

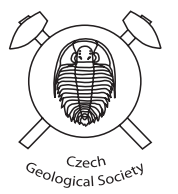

\begin{abstract}
A new computer program TecDIA written in Java, for the application of 35 previously-defined multidimensional diagrams for the tectonomagmatic discrimination of intermediate and acid magmas is briefly described. A detailed Readme document is presented in the Supplementary Electronic Material file. As an innovation, this program provides a ready to publish report containing a synthesis of all diagrams, including the total percent probabilities.

The use of this program is illustrated by two examples of the Bohemian Massif (Czech Republic) for older Carboniferous (granitoids of the Central Bohemian Pluton) and younger Late Carboniferous-Early Permian igneous rocks (volcanics from late Variscan continental basins and granitoids of the Žulová Pluton). According to the results, the tectonic setting for the Early Carboniferous rocks was collisional, whereas for the Late Carboniferous-Early Permian igneous suite it was either a collision or a transition from collisional to a within-plate setting. The acid rocks probably dominated by a crustal component may provide a somewhat different result as compared to the intermediate rocks. TecDIA freely available from http://tlaloc.ier.unam.mx will certainly be useful for all interested in applying these 35 multidimensional diagrams.
\end{abstract}

Keywords: tectonic setting, discriminant function diagrams, multidimensional diagrams

Received: 21 April, 2015; accepted: 2 December, 2015; handling editor: V. Janoušek

The online version of this article (doi: 10.3190/jgeosci.201) contains supplementary electronic material.

\section{Introduction}

Deciphering tectonic setting of older igneous complexes from geochemical criteria (e.g., Pearce and Cann 1971, 1973; Pearce and Norry 1979; Bailey 1981; Shervais 1982; Pearce 1982; Pearce et al. 1984; Wood 1980; Mullen 1983; Butler and Woronow 1986; Meschede 1986; Cabanis and Lecolle 1989; Gorton and Schandl 2000; Agrawal et al. 2004, 2008; Verma et al. 2006, 2013, 2015a; Verma and Agrawal 2011; Verma and Verma 2013; Velikoslavinsky and Krylov 2014; Verma 2015a) has been (and still is) a useful exercise in geological sciences ever since the acceptance of plate tectonics. Nevertheless, most traditional bivariate and ternary diagrams were objectively evaluated and found to be less useful than the newer multidimensional diagrams (Sheth 2008; Verma 2010; Verma et al. 2012; Pandarinath 2014; Rivera-Gómez and Verma in print).
Caution is required while handling compositional data through conventional statistical methods (e.g. Pearson 1897; Chayes 1960, 1971; Aitchison 1984, 1986, 1999; Rollinson 1993; Egozcue et al. 2003; Pawlowsky-Glahn and Egozcue 2006; Agrawal and Verma 2007; Buccianti 2013; Verma 2015a). For a coherent statistical handling of compositional data, Aitchison (1981, 1984, 1986) pioneered the solution in terms of log-ratio transformation prior to the application of conventional statistical tools. More recently, Egozcue et al. (2003) provided another type of log-ratio transformation shown to be mathematically superior although in practice both types of transformations provide similar results (Verma 2015a).

Details on the closure (or constant sum) problem (Chayes 1960, 1971; Aitchison 1986) and possible solutions have been recently summarized by Verma (2015a) who provided the following explanation for the suc- 
cess of such transformations. Compositional data per se cannot be normally distributed because the negative concentrations are automatically prohibited; the ratios of concentrations of two compositional variables become free of the measurement units and can theoretically vary from nearly zero to infinity $(+\infty)$. Natural logarithm of these ratios allows both negative and positive values and opens the space in both directions theoretically from $-\infty$ to $+\infty$. These data will be normally distributed as long as multivariate discordant outliers are identified and eliminated (Verma 2015a).

Additive log-ratio transformation of Aitchison (1986) was used by Verma et al. (2006), Agrawal et al. (2008), and Verma and Agrawal (2011) in development of multidimensional diagrams for basic and ultrabasic rocks (three sets of five diagrams each). A freely available computer program TecD (Verma and Rivera-Gómez 2013), available from http://tlaloc.ier.unam.mx, was written in Visual Basic for an efficient application of these diagrams, including the five by Agrawal et al. (2004) based on adjusted major-element concentrations.

Later, a total of 35 multidimensional diagrams were proposed for intermediate and acid magmatic rocks (Verma et al. 2012, 2013; Verma and Verma 2013). Construction of training databases, log-ratio transformations, discordant outlier detection and elimination, application of statistical tests of F-ratio and U-statistic and other criteria for the choice of chemical elements, multivariate technique of linear discriminant analysis, and probability-based tectonic field boundaries equations were all described by the original authors. For the use of these diagrams, discriminant functions DF1 and DF2 from 70 complex equations must be calculated.

$\mathrm{TecD}$ is incapable of applying these newer 35 diagrams specifically designed for intermediate and acid igneous rocks. The boundaries in these diagrams are based on probability estimates as originally suggested by Agrawal (1999). Furthermore, it would be desirable to estimate individual probabilities for a given sample in a diagram corresponding to the tectonic settings being discriminated (Verma and Agrawal 2011; Verma 2012). This would take into account the actual position of the samples in the individual fields, particularly the distance from the tectonic field boundaries. Complex equations have also to be solved for these probability calculations.

Then, the computed values of DF1 and DF2 functions for each sample could be plotted in 35 multidimensional diagrams with known tectonic field boundaries. Moreover, the samples falling in different fields are to be counted and the corresponding total percentages to be assessed. Alternatively and more importantly, the probability values for a given sample corresponding to each of the three tectonic fields in all 35 diagrams have to be computed from 315 equations ( 9 for each diagram; Verma and Agrawal 2011; Verma 2012) and the total percent probability values synthetised for interpretation.

For these reasons, it was considered necessary to develop a computer program for an efficient, accurate, and routine application of these diagrams. We briefly report on this new computer program, called TecDIA, and illustrate its use for selected acid-intermediate magmatic rocks of the Variscan Bohemian Massif (Czech Republic).

\section{Structure and use of the computer program}

TecDIA (Tectonic Discrimination for Intermediate and Acid magmas), written in Java, is schematically presented in the Electronic Appendix (Fig. S1). In brief, the program needs a correctly formatted $\operatorname{Excel}^{\circledR}$ input file. If only the total iron content is measured as $\mathrm{Fe}_{2} \mathrm{O}_{3}{ }^{\mathrm{t}}$ or $\mathrm{FeO}^{\mathrm{t}}$, the $\mathrm{FeO} / \mathrm{Fe}_{2} \mathrm{O}_{3}$ ratio has to be estimated before an adjustment to $100 \%$ anhydrous basis. This is necessary prior to accessing magma and rock types, in accord with the rules of the International Union of Geological Sciences (Le Bas et al. 1986). Therefore, although frequently done by most researchers, the measured compositions are not recommended to be directly used in the TAS diagram and CIPW norm calculations unless both $\mathrm{FeO}$ and $\mathrm{Fe}_{2} \mathrm{O}_{3}$ values are determined in the laboratory and the major elements are adjusted to $100 \%$ on an anhydrous basis. We recommend the use of a modified version of IgRoCS available from http://tlaloc.ier.unam.mx along with an example datafile in Excel format. This program provides accurate recalculation of major elements before the application of the TAS diagram and CIPW norm calculations. The $\mathrm{FeO} / \mathrm{Fe}_{2} \mathrm{O}_{3}$ ratio is estimated either by the procedure of Le Maitre (1976) or of Middlemost (1989). However, because the original diagrams were proposed for the data adjusted following Middlemost (1989), the same option should be invoked during the IgRoCS preprocessing for the TecDIA software.

TecDIA provides two options for the application of the diagrams: Default and Customized processes (Fig. S1). In the Default process mode, TecDIA applies all 35 diagrams, reports any given diagram set for which complete data are missing for any given sample, applies the appropriate diagram sets (without showing them) depending on whether the rock type is intermediate or acid, computes all probabilities and a synthesis for all samples from the given locality or region (identified in the REGION_TecDIA column of the input file). Two different reports are prepared in the $\operatorname{Excel}^{\circledR}$ format. The first is a file containing seven sheets - three for intermediate rocks (major, major-trace, and trace; Verma and Verma 2013) and four for acid igneous rocks (major of Verma et al. 
2012; major, major-trace, and trace of Verma et al. 2013) for each region or grouping. The second report generates two files (tables) ready to be copied to a Microsoft Word document for publication. The first presents a synthesis of all diagrams for intermediate magmatic rocks, whereas the second is intended for acid ones. If the user has processed several regions in the original data file, this report will present information sequentially for each region.

In the Customized process mode the user can tick the "Generate plots" box for graphical visualization of the data. At this point, he or she is also free to choose to apply a lesser number of diagrams if desired.

The computer program TecDIA and the relevant example files as well as IgRoCS software are available from http://tlaloc.ier.unam.mx. To facilitate the use of TecDIA, we have provided a detailed Readme document in the Electronic Supplement.

\subsection{Intricacies in the programming of TecDIA}

The tectonic settings discriminated from the diagrams for intermediate and acid magmas are as follows: IA (island arc), CA (continental arc), CR (continental rift) and OI (ocean island), $(\mathrm{CR}+\mathrm{OI}$ together known as within-plate, WP), and Col (collision). TecDIA provides a complete synthesis of the results of all five diagrams in a given set. In addition, TecDIA yields a synthesis of the probability estimates for each tectonic setting in all individual diagrams as well as the overall total percent probability estimates of each diagram set.

The equations of discriminant functions DF1-DF2 were reported by Verma et al. $(2012,2013)$ and Verma and Verma (2013), as summarized in tables S1-S3. The major-element based DF1-DF2 equations are of the following type:

$\mathrm{DFn}_{(\mathrm{TF1} 1-\mathrm{TF2} 2 \mathrm{TF3})_{\mathrm{figt}}}=\mathrm{C}_{1} \times \ln \left(\mathrm{TiO}_{2} / \mathrm{SiO}_{2}\right)_{\mathrm{adj}}+\mathrm{C}_{2} \times \ln \left(\mathrm{Al}_{2} \mathrm{O}_{3} /\right.$ $\left.\mathrm{SiO}_{2}\right)_{\mathrm{adj}}+\mathrm{C}_{3} \times \ln \left(\mathrm{Fe}_{2} \mathrm{O}_{3} / \mathrm{SiO}_{2}\right)_{\text {adj }}+\mathrm{C}_{4} \times \ln \left(\mathrm{FeO} / \mathrm{SiO}_{2}\right)_{\text {adj }}$ $+\mathrm{C}_{5} \times \ln \left(\mathrm{MnO} / \mathrm{SiO}_{2}\right)_{\text {adj }}+\mathrm{C}_{6} \times \ln \left(\mathrm{MgO} / \mathrm{SiO}_{2}\right)_{\mathrm{adj}}+\mathrm{C}_{7} \times$ $\ln \left(\mathrm{CaO} / \mathrm{SiO}_{2}\right)_{\text {adj }}+\mathrm{C}_{8} \times \ln \left(\mathrm{Na}_{2} \mathrm{O} / \mathrm{SiO}_{2}\right)_{\mathrm{adj}}+\mathrm{C}_{9} \times \ln \left(\mathrm{K}_{2} \mathrm{O} /\right.$ $\left.\mathrm{SiO}_{2}\right)_{\text {adj }}+\mathrm{C}_{10} \times \ln \left(\mathrm{P}_{2} \mathrm{O}_{5} / \mathrm{SiO}_{2}\right)_{\text {adj }}+\mathrm{C}_{\mathrm{c}}$

where $n$ represents either DF1 (x-axis) or DF2 (y-axis); TF1-TF2-TF3 stand for the three tectonic fields discriminated in a given diagram; figt is the type of diagram for major elements in intermediate (mint by Verma and Verma 2013) or acid magmatic rock ( $m_{3}$ by Verma et al. 2012 or macid by Verma et al. 2013); $C_{1}$ to $C_{10}$ are coefficients for the ten major-element log-ratios obtained from linear discriminant analysis (LDA); $C_{c}$ is the constant term; the subscript adj refers to adjusted data from the SINCLAS (Verma et al. 2002) or IgRoCS (Verma and Rivera-Gómez 2013) computer programs. The actual coefficients are given in Tab. S1. The general equation (A) takes the form of equations (1) to (10) for intermediate rocks (Verma and Verma 2013), (11) to (20) for acid rocks (Verma et al. 2012), and (21) to (30) also for the newer set of acid rocks (Verma et al. 2013). The two major-element based schemes for acid rocks were proposed from different training sets; their use and consistency assures the user that the multidimensional diagrams are robust against the differences in the training sets as long as the initial databases are representative of the entire Earth.

Similarly, for the combined major and trace elements the DF1-DF2 equations are of the following type:

$\mathrm{DFn}_{(\mathrm{TF} 1-\mathrm{TF} 2-\mathrm{TF} 3)_{\text {figt }}}=\mathrm{C}_{1} \times \ln \left(\mathrm{MgO} / \mathrm{TiO}_{2}\right)_{\text {adj }}+\mathrm{C}_{2} \times \ln \left(\mathrm{P}_{2} \mathrm{O}_{5} /\right.$ $\left.\mathrm{TiO}_{2}\right)_{\text {adj }}+\mathrm{C}_{3} \times \ln \left(\mathrm{Nb} / \mathrm{TiO}_{2}\right)_{\mathrm{adj}}+\mathrm{C}_{4} \times \ln \left(\mathrm{Ni} / \mathrm{TiO}_{2}\right)_{\mathrm{adj}}+\mathrm{C}_{5}$ $\times \ln \left(\mathrm{V} / \mathrm{TiO}_{2}\right)_{\mathrm{adj}}+\mathrm{C}_{6} \times \ln \left(\mathrm{Y} / \mathrm{TiO}_{2}\right)_{\mathrm{adj}}+\mathrm{C}_{7} \times \ln \left(\mathrm{Zr} / \mathrm{TiO}_{2}\right)_{\mathrm{adj}}$ $+\mathrm{C}_{\mathrm{c}}$

where the subscript figt is mtacid; other symbols have been explained earlier for equation (A). The approximate coefficient values are summarized in Tab. S2. The general equation (B) can be represented by equations (31) to (40) for intermediate rocks (Verma and Verma 2013) and equations (41) to (50) for acid rocks (Verma et al. 2013).

Finally, for the trace elements the DF1-DF2 equations are of the following type:

$\mathrm{DFn}_{\text {(TF1-TF2-TF3) }_{\text {fort }}}=\mathrm{C}_{1} \times \ln (\mathrm{La} / \mathrm{Yb})_{\text {adj }}+\mathrm{C}_{2} \times \ln (\mathrm{Ce} / \mathrm{Yb})_{\text {adj }}$ $+\mathrm{C}_{3} \times \ln (\mathrm{Sm} / \mathrm{Yb})_{\text {adj }}+\mathrm{C}_{4} \times \ln (\mathrm{Nb} / \mathrm{Yb})_{\text {adj }}+\mathrm{C}_{5} \times \ln (\mathrm{Th} /$

$\mathrm{Yb})_{\text {adj }}+\mathrm{C}_{6} \times \ln (\mathrm{Y} / \mathrm{Yb})_{\text {adj }}+\mathrm{C}_{7} \times \ln (\mathrm{Zr} / \mathrm{Yb})_{\text {adj }}+\mathrm{C}_{\mathrm{c}}$

where the subscript figt is tacid; other symbols have been explained earlier for equation (A). The approximate coefficient values are summarized in Tab. S3. The general equation (B) gives equations (51) to (60) for intermediate (Verma and Verma 2013) and (61) to (70) for acid rocks (Verma et al. 2013).

The equations for probability estimates of individual samples were first presented by Verma and Agrawal (2011) and Verma (2012). These were adopted by the original authors (Verma et al. 2012, 2013; Verma and Verma 2013) for intermediate and acid compositions.

For probability calculations in a diagram of the (TF1-TF2-TF3) figt type, three new functions $\left(s g_{n}\right.$; general equation (E)) have to be calculated from the distances $d_{\text {gn(TFI-TF2-TF3) })_{\text {frt }}}$ (where $n$ varies from 1 to 3; equation (D)) of a given sample from the three group centroids or mean values $\left(m d f 1_{g n}, m d f 2_{g n}\right)$ :

$\mathrm{d}_{\mathrm{gn}(\mathrm{TF1} 1 \mathrm{TF2}-\mathrm{TF3})_{\mathrm{figt}}}=\sqrt{\left(\mathrm{df} 1_{\mathrm{s}}-\mathrm{mdf} 1_{\mathrm{gn}}\right)^{2}+\left(\mathrm{df} 2_{\mathrm{s}}-\mathrm{mdf} 2_{\mathrm{gn}}\right)^{2}}(\mathrm{D})$

$\mathrm{Sg}_{\mathrm{n}}=e^{\left\{-\left(\mathrm{d}_{\mathrm{gn}(\mathrm{TF} 1-\mathrm{TF} 2-\mathrm{TF} 3)_{\mathrm{figt}}}\right)^{2} / 2\right\}}$

The three probabilities of a given sample corresponding to each of the three tectonic fields (TF1-TF2-TF3) $)_{\text {figt }}$ are calculated from the general equation $(\mathrm{F})$ as follows: 

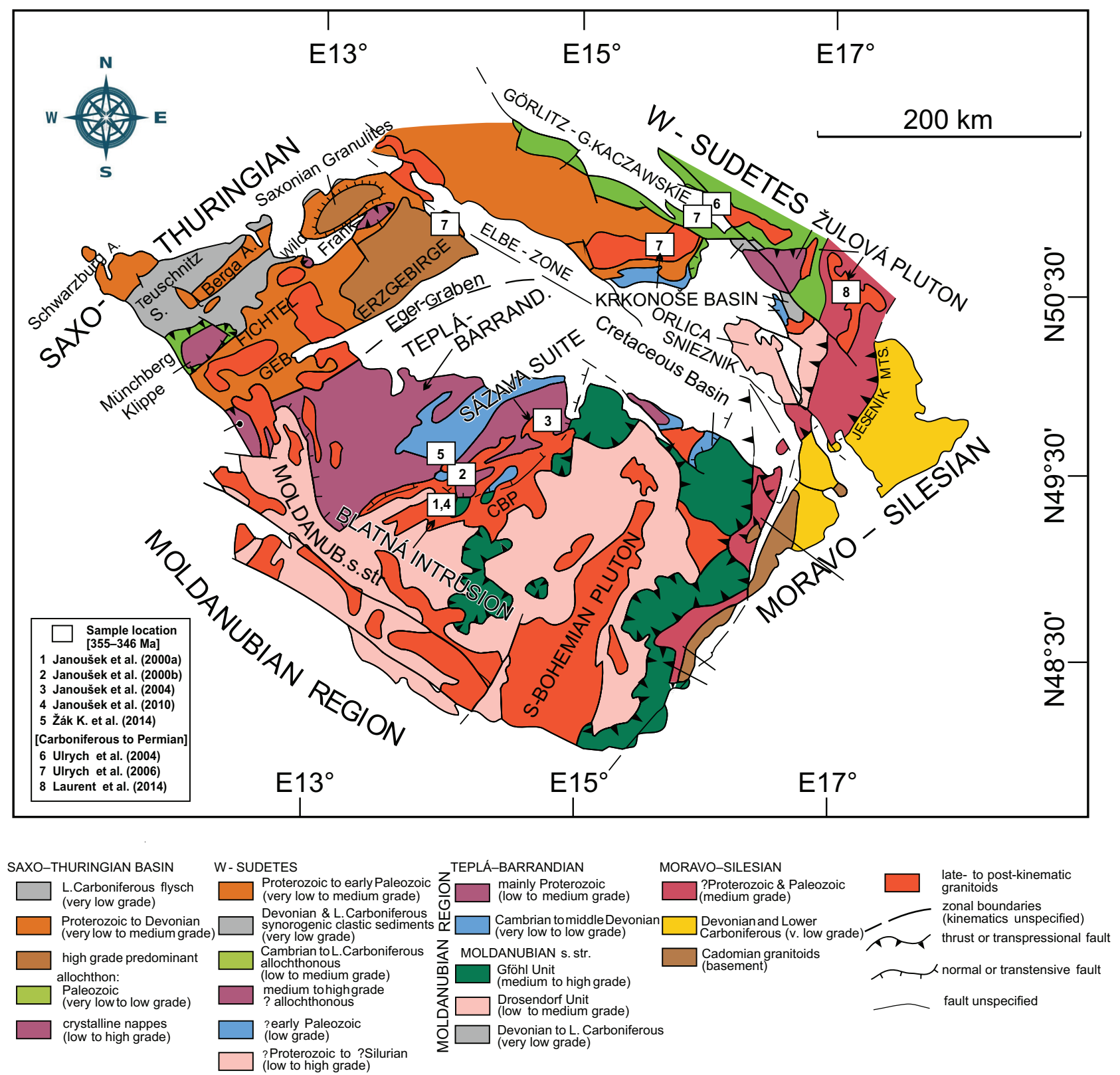

Fig. 1 Simplified geologic map of the Bohemian Massif (modified after Winchester et al. 2002) with schematic sample locations compiled in this work as follows: 1 - Janoušek et al. (2000a); 2 - Janoušek et al. (2000b); 3 - Janoušek et al. (2004); 4 - Janoušek et al. (2010); 5 - Žák K. et al. (2014); 6 - Ulrych et al. (2004); 7 - Ulrych et al. (2006); 8 - Laurent et al. (2014). (CBP) = Central Bohemian Pluton.

$$
\operatorname{Pn}_{\mathrm{s}}=\frac{\mathrm{sg}_{\mathrm{n}}}{\sum_{\mathrm{n}=1}^{3} \mathrm{sg}_{\mathrm{n}}}
$$

Approximate centroid values are reported in Tab. S4. The exact values of centroids from the Statistica ${ }^{\circledR}$ software used earlier for the calculations were programmed in TecDIA. Thus, a total of 315 equations (from (71) to (385); Tab. S4) for the probability estimates were incorporated into TecDIA. As stated by the original authors (Verma and Verma 2013; Verma et al. 2012, 2013), these probability estimates $\left(\mathrm{Pn}_{\mathrm{s}}: \mathrm{P} 1 \mathrm{~s}, \mathrm{P} 2 \mathrm{~s}\right.$, and $\left.\mathrm{P} 3 \mathrm{~s}\right)$ directly provide the inferred tectonic setting for the sample under consideration; the inferred setting is the one for which the corresponding probability $(\mathrm{P} 1 \mathrm{~s}, \mathrm{P} 2 \mathrm{~s}$, or $\mathrm{P} 3 \mathrm{~s})$ is the highest. A sample will plot in the tectonic field TF1, TF2 or TF3 or which it has the highest probability. The actual value of the highest probability also indicates how far away from the tectonic field boundary the sample would actually plot in the field of the inferred tectonic setting. Thus, a simple comparison of the three probabilities provides the inferred tectonic setting for a given sample or a set of samples. Therefore, it is not necessary to plot and count the samples in a diagram, the number of samples is 
Fig. 2 TAS diagram (Le Bas et al. 1986) for the compiled samples of intermediate and acid rocks of Carboniferous and Late Carboniferous to Early Permian ages from the Bohemian Massif (Czech Republic). The $\% \mathrm{~m} / \mathrm{m}$ unit (mass $/$ mass) is suggested by chemists as a replacement for the familiar wt. \% unit and the adjective "adj." refers to the adjusted values from SINCLAS (Verma et al, 2002) or IgRoCS (Verma and Rivera-Gómez 2013). Symbols are explained as insets. The symbols are according to the magma types and their age groups. The abbreviations of rock types are: $\mathrm{PB}$ - picrobasalt; BSN - basanite; $\mathrm{B}$ - basalt; TB - trachybasalt; BA basaltic andesite; A - andesite; BTA - basaltic trachyandesite; TA - trachyandesite; $\mathrm{T}$ - trachyte; D - dacite; TD - trachydacite; and R - rhyolite.

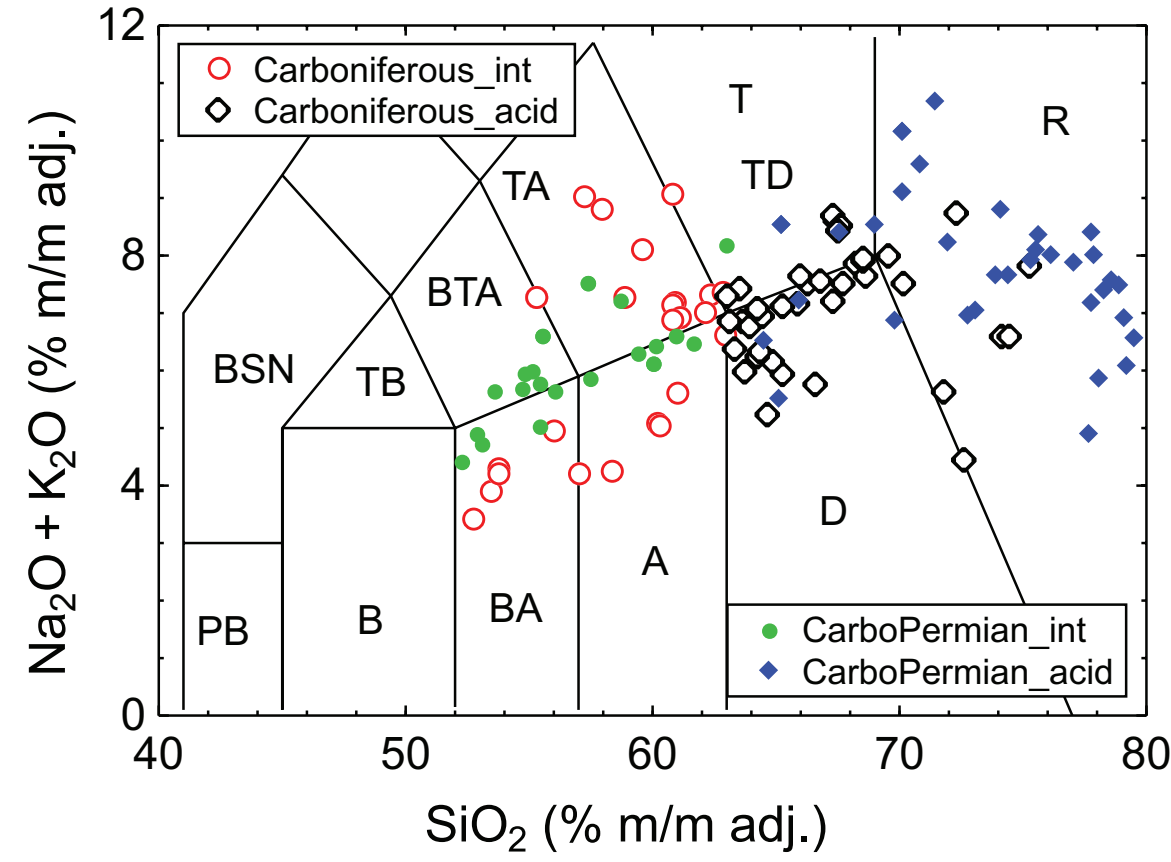

al. 2014) and (2) post-orogenic Late Carboniferous to Early Permian volcanic rocks (Ulrych et al. 2004, 2006) as well as Permian ( $290 \mathrm{Ma})$ intrusive rocks (Žulová Pluton) (Laurent et al. 2014). The latter two sets were treated together because they were similar in age $(\sim 300$ Ma). Locations of the compiled samples are schematically shown in Fig. 1.

After processing in IgRoCS computer program, the data for intermediate and acid rocks are shown in the TAS diagram (Fig. 2). Twenty-seven samples of intermediate and 40 of acid rocks were available for the older Carboniferous age, whereas 24 samples of intermediate and 35 of acid rocks were used for the younger Late Carboniferous to Early Permian age.

The conventional geochemical interpretation was provided by the original authors (Janoušek et al. 2000a, b, 2004, 2010; Ulrych et al. 2004, 2006; Laurent et al. 2014; Žák K. et al. 2014). Here, we summarize the geochemical data (median values for each magma type - intermediate and acid) in a chondrite-normalized rare-earth element (REE) plot (Fig. 3) and primitive mantle-normalized multi-element plot (Fig. 4).

The REE patterns for the Carboniferous granitoids of the CBP are mutually comparable (Fig. 3). This is also true for the younger, Late Carboniferous to Early Permian igneous rocks except for the much larger negative Eu anomaly of the acid types (Fig. 3). However, for each of the igneous suites, the acid rocks do not show significantly higher REE concentrations than the respective intermediate rocks (Fig. 3). It is likely that the acid rocks have a larger crustal component than the intermediate rocks. 

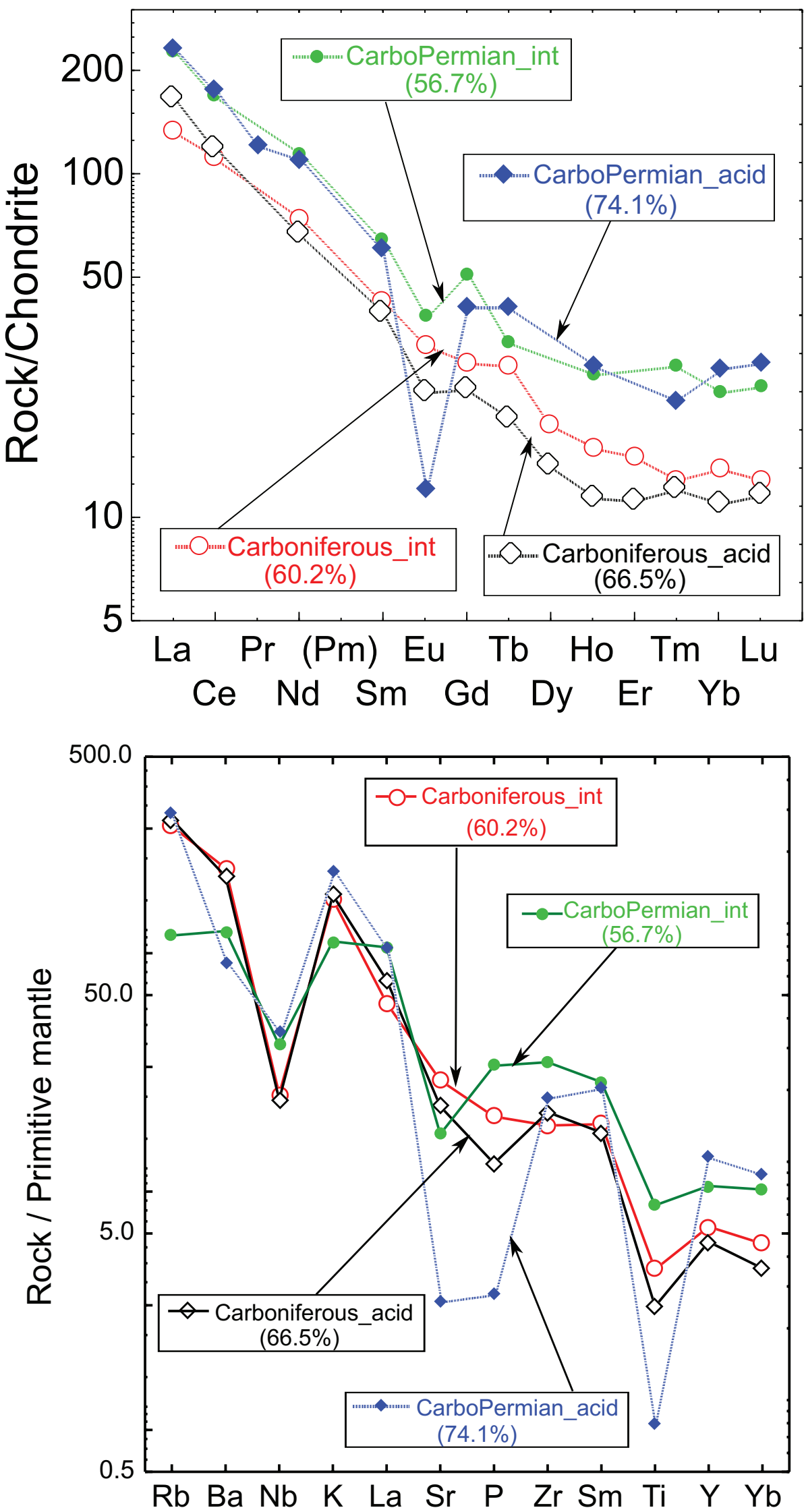

Fig. 3 Chondrite-normalized rare-earth element (REE) plot for the Bohemian Massif samples (chondrite values for normalization from McDonough and Sun 1995); only the median values are used for the sake of simplicity. The symbols are explained as insets. The median adjusted silica values are also reported in brackets next to the magma types.

In a multielement plot (Fig. 4), all magma types show a significant negative $\mathrm{Nb}$ anomaly with respect to $\mathrm{Ba}$ and $\mathrm{K}$. This is also true for $\mathrm{Ti}$ with respect to Sm and Y. In fact, the highly evolved acid rocks (median $\mathrm{SiO}_{2}$ value of about 74 wt. \%) for the Late Carboniferous-Permian age show extreme depletion in Sr, P, and Ti (Fig. 4).

The geochemical data for both magma types (intermediate and acid) from the two selected igneous rock suites of the Bohemian Massif (Fig. 1) were processed in TecDIA and the results are summarized in Tabs 1-4.

Fig. 4 Primitive mantle-normalized multielement plot for the Bohemian Massif samples (primitive mantle values for normalization from Sun and McDonough 1989); only the median values are used for the sake of simplicity. The symbols are explained as insets. The median adjusted silica values are also reported in brackets next to the magma types. 


\subsection{Illustration study 1: Calc-alkaline suites of the Central Bohemian Pluton (Early Carboniferous, 355-346 Ma)}

The intermediate and acid rocks of the CBP (Janoušek et al. 2000a, b, 2004, 2010; Žák K. et al. 2014) constitute our first illustration study. TecDIA provided the results for the seven sets of five diagrams each (Tabs 1-2). We will describe in detail the application of major-element based set for the intermediate rocks. For illustration purposes only, the samples are plotted in Fig. 5 although it is not necessary to plot them at all. The counting of samples, probability calculations for individual samples, and statistical synthesis of individual diagrams are all done by TecDIA (Tab. 1; see also the Readme document in the Electronic Supplement).

The first diagram (Fig. 5a) discriminates the arc (IA + $\mathrm{CA})$, within-plate (CR + OI) and collisional (Col) fields. Besides the tectonic field boundaries that represent equal probability boundaries for the adjacent fields (thick solid lines), two other probability-based boundaries are shown, which correspond to $70 \%$ and $90 \%$ probability for the respective tectonic field with only about $30 \%$ and $10 \%$ combined probability values for the other two fields. The centroid values for the three tectonic fields as reported by the original authors (Verma and Verma 2013) are also shown for reference (Fig. 5a).

Out of 27 samples (plotted in Fig. 5a), eight are in the IA + CA field and the remaining 19 in the Col field (the first row of results in Tab. 1). The respective probability values of the former eight samples are $0.769 \pm$ 0.097 (mean \pm one standard deviation) with the range of 0.5953-0.8860, whereas those for the latter 19 samples are $0.951 \pm 0.110$, with the range of $0.5229-0.9996$ (Tab. 1). No sample falls in the within-plate field, though. However, the results summarized in the first row of results in Tab. 1 do indicate that on the average the 19 samples in the collisional setting plot well inside the field (average probability value of 0.951 ), unlike the 8 samples in the combined arc field (average probability value of 0.769 ).

In the second diagram that discriminates island-arc (IA), continental-arc (CA) and within-plate (CR + OI) settings, samples plot in all three fields; note that the Col field is absent from this diagram (Fig. 5b; Tab. 1).

In the third diagram (IA-CA-Col), 18 samples fall in the $\mathrm{Col}$ field followed by 8 in the IA field (Fig. 5c; Tab. 1, the third row of results). Furthermore, the average probability value for the Col (0.9655) is much higher than that for the IA (0.711). In the fourth diagram (IA-CR + OI-Col), most samples (18) plot in the Col field and only 9 in the IA field (Fig. 5d; Tab. 1). In the final diagram (CA-CR + OI-Col), 20 samples fall in the Col field and 7 in the CA field (Fig. 5e; Tab. 1).
TecDIA also provides a synthesis of all five diagrams (Fig. 5) in the sixth row of Tab. 1 (bold). Out of the total of 135 observations ( $\{\boldsymbol{\Sigma} \boldsymbol{n}\}$ equivalent to five times 27 samples in each diagram), 8 have plotted in the combined arc field, 28 in the IA, 12 in the CA, 12 in the CR + OI, and 75 in the $\mathrm{Col}$ field. The total probability $\{\Sigma$ prob $\}$ values are listed next to these numbers in Tab. 1. Now, our aim is to compute the total percent probability [\%prob] values corresponding to the four tectonic fields (IA, CA, CR + OI, and Col) being discriminated in this set of five diagrams (Fig. 5; Tab. 1). Therefore, the total probability of 8 samples (6.1541) corresponding to the IA + CA field must first be proportionately divided and added to the IA and CA fields, leaving the total probability null value represented by [---] for the IA + CA combined field (Tab. 1). TecDIA provides the highest total percent probability value of $c .63 \%$ for the Col field (Tab. 1). This is followed by c. $22 \%$ for the IA field and even smaller values of c. $8 \%$ and $7 \%$ for the CA and within-plate fields, respectively (Tab. 1).

The by-chance probability for any of these four tectonic settings will be about $25 \%$, whereas the maximum probability for any given tectonic setting will be around $80 \%$ or more (but never $100 \%$ ), because one tectonic setting is absent from one of the five diagrams (Tab. 1). This equal value of by-chance probability for the four tectonic settings being discriminated may be questionable because they do not represent equal magma volumes on the surface of the Earth. Nevertheless, this has to be assumed at present because (1) during the linear discriminant analysis (LDA) of the original datasets, equal probabilities were assigned to each tectonic field (Verma et al. 2012, 2013; Verma and Verma 2013); (2) the alternative of number of samples based probabilities available for the LDA was not used by the original authors; (3) it would be a formidable task to correctly estimate the volume or mass proportions of different types of magmas from different tectonic settings at any given time in the geological history, besides the proportions were likely changing over time; and (4) even if it is done and the volume or mass based bychance probabilities were calculated, they are likely to have too large uncertainties to be of any practical use.

The total percent probability value of $63 \%$ for the Col is significantly higher than the by-chance probability. Therefore, we can interpret the inference of this set of diagrams as indicating a collision tectonic setting (Tab. 1).

Only four samples of intermediate rocks (Tab. 1) were available for the other two sets of diagrams (combined major and trace elements and trace elements only; diagrams not plotted), which could be tentatively used to check the conclusion of the major-element based diagrams. Both sets of diagrams clearly indicated a collision tectonic setting for the Early Carboniferous intermediate rocks of the $\mathrm{CBP}$ (the respective total percent probability values of $85 \%$ for both diagram sets; Tab. 1). 

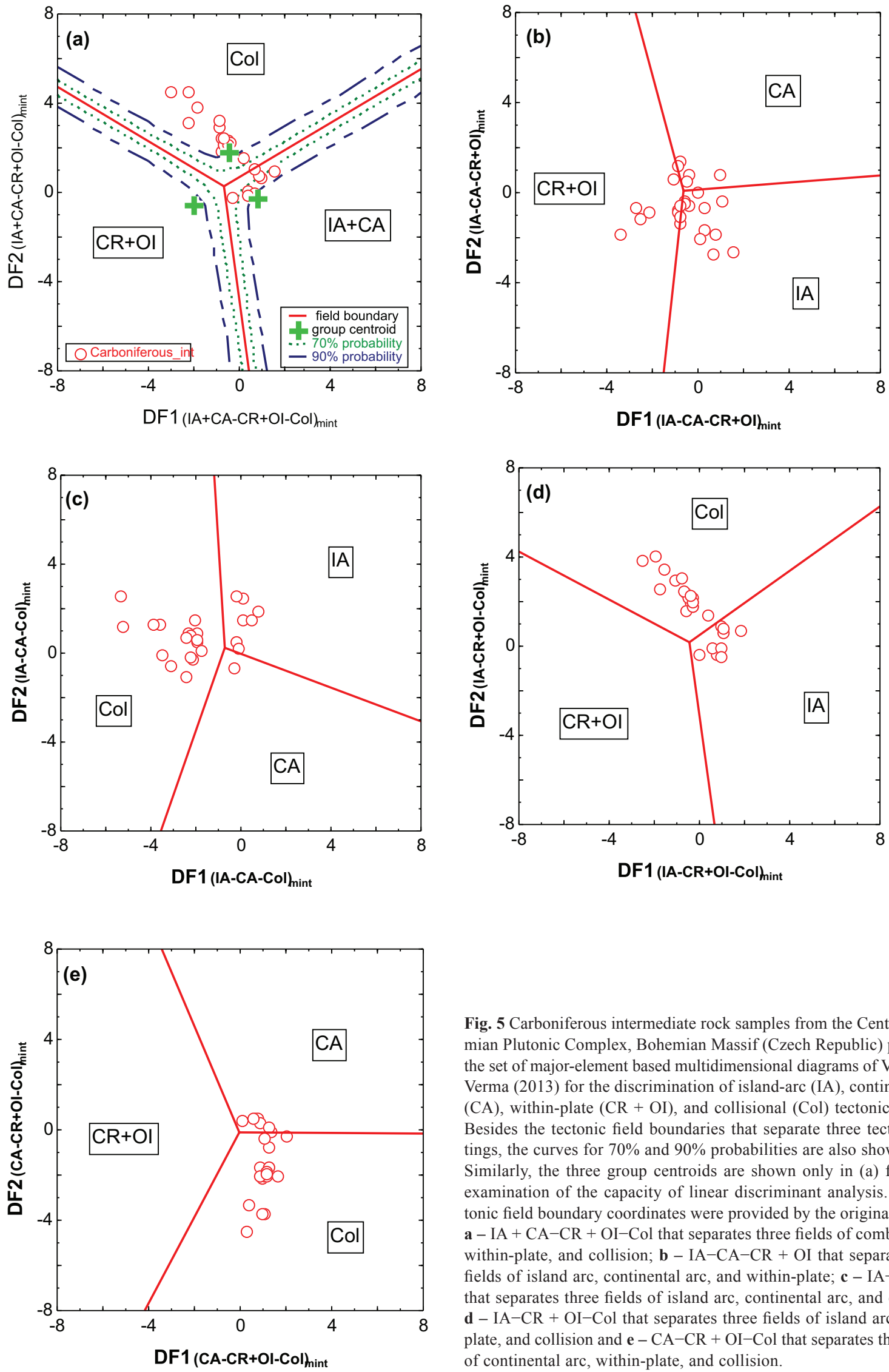

Fig. 5 Carboniferous intermediate rock samples from the Central Bohemian Plutonic Complex, Bohemian Massif (Czech Republic) plotted in the set of major-element based multidimensional diagrams of Verma and Verma (2013) for the discrimination of island-arc (IA), continental-arc (CA), within-plate $(\mathrm{CR}+\mathrm{OI})$, and collisional $(\mathrm{Col})$ tectonic settings. Besides the tectonic field boundaries that separate three tectonic settings, the curves for $70 \%$ and $90 \%$ probabilities are also shown in (a). Similarly, the three group centroids are shown only in (a) for visual examination of the capacity of linear discriminant analysis. The tectonic field boundary coordinates were provided by the original authors. $\mathbf{a}-\mathrm{IA}+\mathrm{CA}-\mathrm{CR}+\mathrm{OI}-\mathrm{Col}$ that separates three fields of combined arc, within-plate, and collision; $\mathbf{b}-\mathrm{IA}-\mathrm{CA}-\mathrm{CR}+\mathrm{OI}$ that separates three fields of island arc, continental arc, and within-plate; $\mathbf{c}-\mathrm{IA}-\mathrm{CA}-\mathrm{Col}$ that separates three fields of island arc, continental arc, and collision; d $-\mathrm{IA}-\mathrm{CR}+\mathrm{OI}-\mathrm{Col}$ that separates three fields of island arc, withinplate, and collision and $\mathbf{e}-\mathrm{CA}-\mathrm{CR}+\mathrm{OI}-\mathrm{Col}$ that separates three fields of continental arc, within-plate, and collision. 
Tab. 2 Application of multidimensional diagrams to Carboniferous (355-346 Ma) acid rocks of the Central Bohemian Plutonic Complex, Czech Republic (Janoušek et al. 2000a, b, 2004, 2010; Žák K. et al. 2014; Illustration study 1; footnote of Tab. 1 gives more explanation)

\begin{tabular}{|c|c|c|c|c|c|c|c|}
\hline \multirow{3}{*}{$\begin{array}{l}\text { Magma type, } \\
\text { Figure name }\end{array}$} & \multirow{3}{*}{ Figure type } & \multirow{3}{*}{$\begin{array}{c}\text { Total } \\
\text { number } \\
\text { of } \\
\text { samples }\end{array}$} & \multicolumn{5}{|c|}{ Number of discriminated samples } \\
\hline & & & & Arc & & Within-plate & Collision \\
\hline & & & $\begin{array}{c}\mathrm{IA}+\mathrm{CA}[\bar{x} \pm s] \\
{\left[\mathrm{p}_{\mathrm{IA}+\mathrm{CA}}\right] \Theta}\end{array}$ & $\begin{array}{c}\mathrm{IA}[\bar{x} \pm s] \\
{\left[\mathrm{p}_{\mathrm{IA}}\right] \Theta}\end{array}$ & $\begin{array}{c}\mathrm{CA}[\bar{x} \pm s] \\
{\left[\mathrm{p}_{\mathrm{CA}}\right] \Theta}\end{array}$ & $\begin{array}{c}\mathrm{CR}+\mathrm{OI}[\bar{x} \pm s] \\
{\left[\mathrm{p}_{\mathrm{CR}+\mathrm{OI}}\right] \Theta}\end{array}$ & $\begin{array}{c}\mathrm{Col}[\bar{x} \pm s] \\
{\left[\mathrm{p}_{\mathrm{Col}}\right] \Theta}\end{array}$ \\
\hline \multirow{5}{*}{$\begin{array}{l}\text { Acid; Verma et al. } \\
(2012) \text {; log-ratios of } \\
\text { all major elements }\end{array}$} & $\mathrm{IA}+\mathrm{CA}-\mathrm{CR}-\mathrm{Col}$ & 40 & $\begin{array}{r}24[0.654 \pm 0.171] \\
(0.4098-0.9716)\end{array}$ & --- & -- & $0(0)$ & $\begin{array}{r}16[0.669 \pm 0.178] \\
(0.4413-0.9959)\end{array}$ \\
\hline & IA-CA-CR & 40 & --- & $\begin{array}{l}3[0.636 \pm 0.088] \\
(0.5532-0.7286)\end{array}$ & $\begin{array}{r}30[0.723 \pm 0.128] \\
(0.4673-0.9109)\end{array}$ & $\begin{array}{l}7[0.786 \pm 0.105] \\
(0.5737-0.8819)\end{array}$ & -- \\
\hline & IA-CA-Col & 40 & --- & $\begin{array}{l}4[0.557 \pm 0.104] \\
(0.4748-0.7084)\end{array}$ & $\begin{array}{r}24[0.607 \pm 0.065] \\
(0.4872-0.7296)\end{array}$ & -- & $\begin{array}{r}12[0.809 \pm 0.188] \\
(0.4728-0.9975)\end{array}$ \\
\hline & $\mathrm{IA}-\mathrm{CR}-\mathrm{Col}$ & 40 & --- & $\begin{array}{r}11[0.732 \pm 0.225] \\
(0.3813-0.9914)\end{array}$ & -- & $\begin{array}{l}2[0.454 \pm 0.050] \\
(0.4188,0.4896)\end{array}$ & $\begin{array}{r}27[0.663 \pm 0.169] \\
(0.3646-0.9957)\end{array}$ \\
\hline & $\mathrm{CA}-\mathrm{CR}-\mathrm{Col}$ & 40 & --- & -- & $\begin{array}{r}13[0.830 \pm 0.208] \\
(0.3858-0.9904)\end{array}$ & $1(0.4502)$ & $\begin{array}{r}26[0.613 \pm 0.143] \\
(0.4202-0.9894)\end{array}$ \\
\hline $\begin{array}{l}\text { Illustration study } 1 . \\
\text { Diagrams based on } \\
\text { log-ratios of major } \\
\text { elements }\end{array}$ & $\begin{array}{c}\{\Sigma n\}\{\Sigma p r o b\} \\
{[\% \text { prob] }}\end{array}$ & 200 & 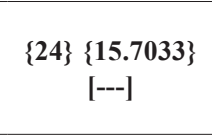 & $\begin{array}{c}\{18\}\{12.1886\} \\
{[11.3 \%]}\end{array}$ & $\begin{array}{c}\{67\}\{47.0410\} \\
{[43.7 \%]}\end{array}$ & $\begin{array}{c}\{10\}\{6.8635\} \\
{[5.0 \%]}\end{array}$ & $\begin{array}{c}\{81\}\{54.2589\} \\
{[40.0 \%]}\end{array}$ \\
\hline \multirow{5}{*}{$\begin{array}{l}\text { Acid; Verma et al. } \\
\text { (2013); log-ratios of } \\
\text { all major elements }\end{array}$} & $\mathrm{IA}+\mathrm{CA}-\mathrm{CR}+\mathrm{OI}-\mathrm{Col}$ & 40 & $\begin{array}{r}17[0.612 \pm 0.190] \\
(0.3743-0.9622)\end{array}$ & --- & --- & $0(0)$ & $\begin{array}{r}23[0.565 \pm 0.176] \\
(0.3763-0.9875)\end{array}$ \\
\hline & $\mathrm{IA}-\mathrm{CA}-\mathrm{CR}+\mathrm{OI}$ & 40 & --- & $\begin{array}{l}2[0.604 \pm 0.122] \\
(0.5176,0.6904)\end{array}$ & $\begin{array}{r}26[0.731 \pm 0.110] \\
(0.4030-0.9360)\end{array}$ & $\begin{array}{r}12[0.805 \pm 0.176] \\
(0.4209-0.9743)\end{array}$ & --- \\
\hline & IA-CA-Col & 40 & --- & $\begin{array}{r}2[0.4970 \pm 0.0381] \\
(0.4700,0.5239)\end{array}$ & $\begin{array}{r}20[0.704 \pm 0.124] \\
(0.4987-0.9039)\end{array}$ & -- & $\begin{array}{r}18[0.762 \pm 0.219] \\
(0.3787-0.9992)\end{array}$ \\
\hline & $\mathrm{IA}-\mathrm{CR}+\mathrm{OI}-\mathrm{Col}$ & 40 & --- & $\begin{array}{l}4[0.832 \pm 0.095] \\
(0.7098-0.9316)\end{array}$ & $-\ldots$ & $\begin{array}{r}11[0.551 \pm 0.059] \\
(0.4654-0.6599)\end{array}$ & $\begin{array}{r}25[0.637 \pm 0.105] \\
(0.4660-0.9802)\end{array}$ \\
\hline & $\mathrm{CA}-\mathrm{CR}+\mathrm{OI}-\mathrm{Col}$ & 40 & --- & -- & $\begin{array}{r}15[0.697 \pm 0.192] \\
(0.4416-0.9789)\end{array}$ & $1(0.4684)$ & $\begin{array}{r}24[0.577 \pm 0.158] \\
(0.3479-0.9798) \\
\end{array}$ \\
\hline $\begin{array}{l}\text { Illustration study } 1 . \\
\text { Diagrams based on } \\
\text { log-ratios of major } \\
\text { elements }\end{array}$ & $\begin{array}{c}\{\Sigma n\}\{\Sigma p r o b\} \\
{[\% \text { prob] }}\end{array}$ & 200 & 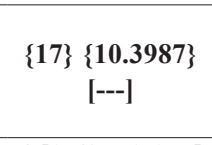 & $\begin{array}{c}\{8\}\{5.5284\} \\
{[5.1 \%]}\end{array}$ & $\begin{array}{c}\{61\}\{43.5515\} \\
{[39.9 \%]}\end{array}$ & $\begin{array}{c}\{24\}\{16.1927\} \\
{[12.3 \%]}\end{array}$ & $\begin{array}{c}\{90\}\{56.4903\} \\
{[42.7 \%]}\end{array}$ \\
\hline \multirow{5}{*}{$\begin{array}{l}\text { Acid; Verma et al. } \\
\text { (2013); log-ratios of } \\
\text { major and immobile } \\
\text { trace elements }\end{array}$} & $\mathrm{IA}+\mathrm{CA}-\mathrm{CR}+\mathrm{OI}-\mathrm{Col}$ & 10 & $\begin{array}{l}4[0.697 \pm 0.155] \\
(0.4663-0.7902)\end{array}$ & --- & --- & $1(0.5317)$ & $\begin{array}{l}5[0.659 \pm 0.146] \\
(0.4926-0.8405)\end{array}$ \\
\hline & $\mathrm{IA}-\mathrm{CA}-\mathrm{CR}+\mathrm{OI}$ & 10 & --- & $0(0)$ & $\begin{array}{l}9[0.737 \pm 0.089] \\
(0.5536-0.8398)\end{array}$ & $1(0.6193)$ & --- \\
\hline & $\mathrm{IA}-\mathrm{CA}-\mathrm{Col}$ & 10 & --- & $0(0)$ & $\begin{array}{l}6[0.667 \pm 0.106] \\
(0.5316-0.7997)\end{array}$ & --- & $\begin{array}{l}4[0.607 \pm 0.142] \\
(0.4437-0.7805)\end{array}$ \\
\hline & $\mathrm{IA}-\mathrm{CR}+\mathrm{OI}-\mathrm{Col}$ & 10 & --- & $1(0.4285)$ & --- & $1(0.5449)$ & $\begin{array}{l}8[0.691 \pm 0.193] \\
(0.3705-0.8810)\end{array}$ \\
\hline & $\mathrm{CA}-\mathrm{CR}+\mathrm{OI}-\mathrm{Col}$ & 10 & --- & --- & $\begin{array}{l}6[0.654 \pm 0.187] \\
(0.4431-0.8306)\end{array}$ & $1(0.5309)$ & $\begin{array}{l}3[0.673 \pm 0.124] \\
(0.5371-0.7813)\end{array}$ \\
\hline $\begin{array}{l}\text { Illustration study } 1 . \\
\text { Diagrams based on } \\
\text { log-ratios of major } \\
\text { and immobile trace } \\
\text { elements }\end{array}$ & $\begin{array}{c}\{\Sigma n\}\{\Sigma p r o b\} \\
{[\% \text { prob] }}\end{array}$ & 50 & 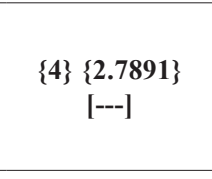 & $\begin{array}{c}\{1\}\{0.4285\} \\
{[2 \%]}\end{array}$ & $\begin{array}{c}\{21\}\{14.5622\} \\
{[51 \%]}\end{array}$ & $\begin{array}{c}\{4\}\{2.2267\} \\
{[7 \%]}\end{array}$ & $\begin{array}{c}\{20\}\{13.2689\} \\
{[40 \%]}\end{array}$ \\
\hline \multirow{5}{*}{$\begin{array}{l}\text { Acid; Verma et al. } \\
(2013) \text {; log-ratios } \\
\text { of immobile trace } \\
\text { elements }\end{array}$} & $\mathrm{IA}+\mathrm{CA}-\mathrm{CR}+\mathrm{OI}-\mathrm{Col}$ & 6 & $0(0)$ & --- & --- & $0(0)$ & $\begin{array}{l}6[0.718 \pm 0.120] \\
(0.4921-0.8185)\end{array}$ \\
\hline & IA-CA-CR + OI & 6 & --- & $0(0)$ & $\begin{array}{l}6[0.943 \pm 0.096] \\
(0.7474-0.9965)\end{array}$ & $0(0)$ & --- \\
\hline & IA-CA-Col & 6 & --- & $0(0)$ & $1(0.6094)$ & --- & $\begin{array}{l}5[0.702 \pm 0.067] \\
(0.6317-0.7952)\end{array}$ \\
\hline & IA-CR + OI-Col & 6 & --- & $0(0)$ & --- & $0(0)$ & $\begin{array}{c}6[0.9750 \pm 0.0148] \\
(0.9556-0.9950)\end{array}$ \\
\hline & $\mathrm{CA}-\mathrm{CR}+\mathrm{OI}-\mathrm{Col}$ & 6 & --- & --- & $1(0.6768)$ & $0(0)$ & $\begin{array}{l}5[0.735 \pm 0.071] \\
(0.6643-0.8250)\end{array}$ \\
\hline $\begin{array}{l}\text { Illustration study } 1 . \\
\text { Diagrams based on } \\
\text { log-ratios of immo- } \\
\text { bile trace elements }\end{array}$ & $\begin{array}{c}\{\Sigma n\}\left\{\sum \text { prob }\right\} \\
{[\% \text { prob }]}\end{array}$ & 30 & $\begin{array}{c}\{0\}\{0\} \\
{[0 \%]}\end{array}$ & $\begin{array}{c}\{0\}\{0\} \\
{[0 \%]}\end{array}$ & $\begin{array}{c}\{8\}\{6.9434\} \\
{[29 \%]}\end{array}$ & $\begin{array}{c}\{0\}\{0\} \\
{[0 \%]}\end{array}$ & $\begin{array}{c}\{22\}\{17.3420\} \\
{[71 \%]}\end{array}$ \\
\hline
\end{tabular}


Tab. 3 Application of multidimensional diagrams to Late Carboniferous to Early Permian intermediate rocks of the Bohemian Massif, Czech Republic (Ulrych et al. 2004, 2006; Laurent et al. 2014; Illustration study 2, footnote of Tab. 1 gives more explanation)

\begin{tabular}{|c|c|c|c|c|c|c|c|}
\hline \multirow{3}{*}{$\begin{array}{l}\text { Magma type, } \\
\text { Figure name }\end{array}$} & \multirow{3}{*}{ Figure type } & \multirow{3}{*}{$\begin{array}{c}\text { Total } \\
\text { number } \\
\text { of } \\
\text { samples }\end{array}$} & \multicolumn{5}{|c|}{ Number of discriminated samples } \\
\hline & & & & Arc & & Within-plate & Collision \\
\hline & & & $\begin{array}{c}\mathrm{IA}+\mathrm{CA}[\bar{x} \pm s] \\
{\left[\mathrm{p}_{\mathrm{IA}+\mathrm{CA}}\right] \Theta}\end{array}$ & $\begin{array}{c}\mathrm{IA}[\bar{x} \pm s] \\
{\left[\mathrm{p}_{\mathrm{IA}}\right] \Theta}\end{array}$ & $\begin{array}{c}\mathrm{CA}[\bar{x} \pm s] \\
{\left[\mathrm{p}_{\mathrm{CA}}\right] \Theta}\end{array}$ & $\begin{array}{c}\mathrm{CR}+\mathrm{OI}[\bar{x} \pm s] \\
{\left[\mathrm{p}_{\mathrm{CR}+\mathrm{OI}}\right] \Theta}\end{array}$ & $\begin{array}{c}\mathrm{Col}[\bar{x} \pm s] \\
{\left[\mathrm{p}_{\mathrm{Col}}\right] \Theta}\end{array}$ \\
\hline \multirow{5}{*}{$\begin{array}{l}\text { Intermediate; Verma } \\
\text { and Verma (2013); } \\
\text { log-ratios of all } \\
\text { major elements }\end{array}$} & $\mathrm{IA}+\mathrm{CA}-\mathrm{CR}-$ & 24 & $1(0.5404)$ & -- & -- & $\begin{array}{c}13[0.773 \pm 0.175] \\
(0.4775-0.9701)\end{array}$ & $\begin{array}{c}10[0.895 \pm 0.151] \\
(0.4972-0.9945)\end{array}$ \\
\hline & $\mathrm{IA}-\mathrm{CA}-\mathrm{CR}+\mathrm{OI}$ & 24 & --- & $0(0)$ & $\begin{array}{c}6[0.611 \pm 0.155] \\
(0.4707-0.8740)\end{array}$ & $\begin{array}{l}18[0.834 \pm 0.159] \\
(0.5787-0.9984)\end{array}$ & --- \\
\hline & IA-CA-Col & 24 & --- & $1(0.7543)$ & $\begin{array}{l}5[0.710 \pm 0.145] \\
(0.6152-0.9459)\end{array}$ & -- & $\begin{array}{l}18[0.813 \pm 0.178] \\
(0.4821-0.9992)\end{array}$ \\
\hline & $\mathrm{IA}-\mathrm{CR}+\mathrm{OI}-\mathrm{Col}$ & 24 & --- & $1(0.5575)$ & -- & $\begin{array}{r}14[0.770 \pm 0.171] \\
(0.5044-0.9748)\end{array}$ & $\begin{array}{l}9[0.953 \pm 0.048] \\
(0.8720-0.9930)\end{array}$ \\
\hline & $\mathrm{CA}-\mathrm{CR}+\mathrm{OI}-\mathrm{Col}$ & 24 & --- & --- & $1(0.7265)$ & $\begin{array}{c}12[0.816 \pm 0.146] \\
(0.4918-0.9803)\end{array}$ & $\begin{array}{l}11[0.810 \pm 0.187] \\
(0.4709-0.9711)\end{array}$ \\
\hline $\begin{array}{l}\text { Illustration study } 1 . \\
\text { Diagrams based on } \\
\text { log-ratios of major } \\
\text { elements }\end{array}$ & $\begin{array}{c}\{\Sigma n\}\{\Sigma \text { prob }\} \\
{[\% \text { prob }]}\end{array}$ & 120 & $\begin{array}{c}\{1\}\{0.5404\} \\
{[---]}\end{array}$ & $\begin{array}{c}\{2\}\{1.3118\} \\
{[1.4 \%]}\end{array}$ & $\begin{array}{c}\{12\}\{7.9422\} \\
{[8.7 \%]}\end{array}$ & $\begin{array}{c}\{57\}\{45.6262\} \\
{[47.3 \%]}\end{array}$ & $\begin{array}{c}\{48\}\{41.0712\} \\
{[42.6 \%]}\end{array}$ \\
\hline \multirow{5}{*}{$\begin{array}{l}\text { Intermediate; Verma } \\
\text { and Verma (2013); } \\
\text { log-ratios of major } \\
\text { and immobile trace } \\
\text { elements }\end{array}$} & $\mathrm{IA}+\mathrm{CA}-\mathrm{CR}+\mathrm{OI}-\mathrm{Col}$ & 21 & $0(0)$ & --- & --- & $\begin{array}{r}16[0.845 \pm 0.159] \\
(0.5335-0.9917)\end{array}$ & $\begin{array}{l}5[0.650 \pm 0.061] \\
(0.5845-0.7018)\end{array}$ \\
\hline & $\mathrm{IA}-\mathrm{CA}-\mathrm{CR}+\mathrm{OI}$ & 21 & --- & $0(0)$ & $\begin{array}{c}2[0.42220 \pm 0.00000] \\
\quad(0.4222,0.4222)\end{array}$ & $\begin{array}{c}19[0.910 \pm 0.133] \\
(0.5831-0.9995)\end{array}$ & --- \\
\hline & IA-CA-Col & 21 & --- & $0(0)$ & $0(0)$ & --- & $\begin{array}{c}21[0.869 \pm 0.130] \\
(0.5272-0.9963)\end{array}$ \\
\hline & $\mathrm{IA}-\mathrm{CR}+\mathrm{OI}-\mathrm{Col}$ & 21 & --- & $0(0)$ & --- & $\begin{array}{c}16[0.844 \pm 0.156] \\
(0.5570-0.9902)\end{array}$ & $\begin{array}{c}5[0.626 \pm 0.061] \\
(0.5584-0.6725)\end{array}$ \\
\hline & $\mathrm{CA}-\mathrm{CR}+\mathrm{OI}-\mathrm{Col}$ & 21 & --- & --- & $0(0)$ & $\begin{array}{c}16[0.851 \pm 0.152] \\
(0.5242-0.9914)\end{array}$ & $\begin{array}{c}5[0.602 \pm 0.116] \\
(0.4971-0.7247)\end{array}$ \\
\hline $\begin{array}{l}\text { Illustration study } 1 . \\
\text { Diagrams based on } \\
\text { log-ratios of major } \\
\text { and immobile trace }\end{array}$ & $\begin{array}{c}\{\Sigma n\}\{\Sigma p r o b\} \\
{[\% \text { prob }]}\end{array}$ & 105 & $\begin{array}{c}\{0\}\{0\} \\
{[0 \%]}\end{array}$ & $\begin{array}{c}\{0\}\{0\} \\
{[0 \%]}\end{array}$ & $\begin{array}{c}\{2\}\{0.8444\} \\
{[1.0 \%]}\end{array}$ & $\begin{array}{c}\{67\}\{57.9290\} \\
{[67.0 \%]}\end{array}$ & $\begin{array}{c}\{36\}\{27.6400\} \\
{[32.0 \%]}\end{array}$ \\
\hline \multirow{5}{*}{$\begin{array}{l}\text { Intermediate; Verma } \\
\text { and Verma (2013); } \\
\text { log-ratios of immo- } \\
\text { bile trace elements }\end{array}$} & $\mathrm{IA}+\mathrm{CA}-\mathrm{CR}+\mathrm{OI}-\mathrm{Col}$ & 22 & $\begin{array}{l}6[0.569 \pm 0.093] \\
(0.4566-0.7108)\end{array}$ & --- & --- & $\begin{array}{l}8[0.718 \pm 0.149] \\
(0.4703-0.8892)\end{array}$ & $\begin{array}{l}8[0.790 \pm 0.203] \\
(0.4731-0.9927)\end{array}$ \\
\hline & $\mathrm{IA}-\mathrm{CA}-\mathrm{CR}+\mathrm{OI}$ & 22 & --- & $0(0)$ & $\begin{array}{c}12[0.841 \pm 0.116] \\
(0.5544-0.9959)\end{array}$ & $\begin{array}{r}10[0.864 \pm 0.159] \\
(0.5867-0.9990)\end{array}$ & --- \\
\hline & $\mathrm{IA}-\mathrm{CA}-\mathrm{Col}$ & 22 & --- & $0(0)$ & $\begin{array}{l}9[0.692 \pm 0.098] \\
(0.5654-0.8482)\end{array}$ & 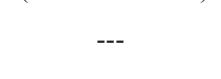 & $\begin{array}{c}13[0.840 \pm 0.185] \\
(0.4923-0.9951)\end{array}$ \\
\hline & $\mathrm{IA}-\mathrm{CR}+\mathrm{OI}-\mathrm{Col}$ & 22 & --- & $1(0.3932)$ & --- & $\begin{array}{l}8[0.728 \pm 0.119] \\
(0.4933-0.8728)\end{array}$ & $\begin{array}{r}13[0.718 \pm 0.206] \\
(0.3727-0.9963)\end{array}$ \\
\hline & $\mathrm{CA}-\mathrm{CR}+\mathrm{OI}-\mathrm{Col}$ & 22 & --- & --- & $\begin{array}{l}6[0.719 \pm 0.069] \\
(0.6512-0.8165)\end{array}$ & $\begin{array}{l}8[0.683 \pm 0.172] \\
(0.4097-0.8669)\end{array}$ & $\begin{array}{l}8[0.710 \pm 0.240] \\
(0.4156-0.9783)\end{array}$ \\
\hline $\begin{array}{l}\text { Diagrams based on } \\
\text { log-ratios of immo- } \\
\text { bile trace elements }\end{array}$ & $\begin{array}{c}\{\Sigma n\}\{\Sigma \text { prob }\} \\
{[\% \text { prob }]}\end{array}$ & 110 & $\begin{array}{c}\{6\}\{3.4158\} \\
{[---]}\end{array}$ & $\begin{array}{c}\{1\}\{0.3932\} \\
{[0.6 \%]}\end{array}$ & $\begin{array}{c}\{27\}\{20.6386\} \\
{[29.0 \%]}\end{array}$ & $\begin{array}{c}\{34\}\{25.6728\} \\
{[31.2 \%]}\end{array}$ & $\begin{array}{c}\{42\}\{32.2574\} \\
{[39.2 \%]}\end{array}$ \\
\hline
\end{tabular}

set also yield a transitional continental arc to collision tectonic setting (Tab. 2). Only six samples used in the immobile trace-element based diagram set are more consistent with a collisional setting (Tab. 2).

\subsection{Illustration study 2: Volcanics and Žulová Pluton (Late Carboniferous to Early Permian, $300 \mathrm{Ma}$ )}

Our second study invokes whole-rock geochemical data for extrusive and intrusive rocks reported, respectively, by Ulrych et al. (2004, 2006) and Laurent et al. (2014).
TecDIA provided the results of intermediate and acid rocks summarized in Tabs 3 and 4, respectively.

For the intermediate volcanics (21 samples) and the Žulová Pluton granitoids (3 samples) (Tab. 3), the major-element based diagram set suggests a transitional collision to within-plate setting with the respective percent probability values of $c .43 \%$ and $47 \%$. However, 21 samples in the combined major- and trace-element based diagram set clearly indicate a within-plate setting with total percent probability value of $67 \%$. Unfortunately, the final set of diagrams of intermediate rocks failed to provide any meaningful result because the samples were 
Tab. 4 Application of multidimensional diagrams to Late Carboniferous to Early Permian acid igneous rocks of Bohemian Massif, Czech Republic (Ulrych et al. 2004, 2006; Laurent et al. 2014; Illustration study 2, footnote of Tab. 1 gives more explanation)

\begin{tabular}{|c|c|c|c|c|c|c|c|}
\hline \multirow{3}{*}{$\begin{array}{l}\text { Magma type, } \\
\text { Figure name }\end{array}$} & \multirow{3}{*}{ Figure type } & \multirow{3}{*}{$\begin{array}{c}\text { Total } \\
\text { number } \\
\text { of } \\
\text { samples }\end{array}$} & \multicolumn{5}{|c|}{ Number of discriminated samples } \\
\hline & & & \multicolumn{3}{|c|}{ Arc } & \multirow{2}{*}{$\begin{array}{c}\text { Within-plate } \\
\mathrm{CR}+\mathrm{OI}[\bar{x} \pm s] \\
{\left[\mathrm{p}_{\mathrm{CR}+\mathrm{OI}}\right] \Theta}\end{array}$} & \multirow{2}{*}{$\begin{array}{c}\text { Collision } \\
\text { Col }[\bar{x} \pm s] \\
{\left[\mathrm{p}_{\mathrm{Col}}\right] \Theta}\end{array}$} \\
\hline & & & $\begin{array}{c}\mathrm{IA}+\mathrm{CA}[\bar{x} \pm s] \\
{\left[\mathrm{p}_{\mathrm{IA}+\mathrm{CA}}\right] \Theta}\end{array}$ & $\begin{array}{c}\text { IA }[\bar{x} \pm s] \\
{\left[\mathrm{p}_{\mathrm{IA}}\right] \Theta}\end{array}$ & $\begin{array}{c}\mathrm{CA}[\bar{x} \pm s] \\
{\left[\mathrm{p}_{\mathrm{CA}}\right] \Theta}\end{array}$ & & \\
\hline \multirow{5}{*}{$\begin{array}{l}\text { Acid; Verma et al. } \\
(2012) \text {; log-ratios of } \\
\text { all major elements }\end{array}$} & $\mathrm{IA}+\mathrm{CA}-\mathrm{CR}-\mathrm{Col}$ & 35 & $\begin{array}{l}2[0.684 \pm 0.163] \\
(0.5689,0.7987)\end{array}$ & -- & --- & $0(0)$ & $\begin{array}{c}33[0.844 \pm 0.130] \\
(0.4461-0.9919)\end{array}$ \\
\hline & IA-CA-CR & 35 & --- & $0(0)$ & $\begin{array}{l}11[0.727 \pm 0.163] \\
(0.4800-0.9486)\end{array}$ & $\begin{array}{r}24[0.967 \pm 0.058] \\
(0.8135-1.0000)\end{array}$ & --- \\
\hline & IA-CA-Col & 35 & --- & $0(0)$ & $\begin{array}{c}2[0.6056 \pm 0.0105] \\
(0.5982,0.6131)\end{array}$ & -- & $\begin{array}{r}33[0.954 \pm 0.096] \\
(0.5582-1.0000)\end{array}$ \\
\hline & IA-CR-Col & 35 & --- & $\begin{array}{l}2[0.581 \pm 0.262] \\
(0.3953,0.7663)\end{array}$ & ) --- & $1(0.4879)$ & $\begin{array}{r}32[0.857 \pm 0.124] \\
(0.5959-0.9858)\end{array}$ \\
\hline & $\mathrm{CA}-\mathrm{CR}-\mathrm{Col}$ & 35 & --- & -- & $\begin{array}{l}3[0.697 \pm 0.2 \\
(0.3747-0.9\end{array}$ & $1(0.4800)$ & $\begin{array}{c}31[0.806 \pm 0.103] \\
(0.4923-0.9519)\end{array}$ \\
\hline $\begin{array}{l}\text { Illustration study } 2 . \\
\text { Diagrams based on } \\
\text { log-ratios of major } \\
\text { elements }\end{array}$ & $\begin{array}{c}\{\Sigma n\}\{\Sigma \text { prob }\} \\
{[\% \text { prob }]}\end{array}$ & 175 & $\begin{array}{c}\{2\}\{1.3675\} \\
{[---]}\end{array}$ & $\begin{array}{c}\{2\}\{1.1616\} \\
{[0.9 \%]}\end{array}$ & $\begin{array}{c}\{16\}\{11.2936\} \\
{[8.4 \%]}\end{array}$ & $\begin{array}{c}\{26\}\{24.1718\} \\
{[16.1 \%]}\end{array}$ & $\begin{array}{c}\{129\}\{111.7057\} \\
{[74.6 \%]}\end{array}$ \\
\hline \multirow{6}{*}{$\begin{array}{l}\text { Acid; Verma et al. } \\
\text { (2013); log-ratios of } \\
\text { all major elements }\end{array}$} & $\mathrm{IA}+\mathrm{CA}-\mathrm{CR}+\mathrm{OI}-\mathrm{Col}$ & 35 & $\begin{array}{c}{[0.706 \pm 0.149]} \\
(0.6012,0.8116)\end{array}$ & --- & --- & $\begin{array}{l}4[0.542 \pm 0.085] \\
(0.4698-0.6630)\end{array}$ & $\begin{array}{c}29[0.855 \pm 0.117] \\
(0.5558-0.9885)\end{array}$ \\
\hline & & & & & $4[0.745 \pm 0.149] 3$ & $31[0.9485$ & \\
\hline & $\mathrm{IA}-\mathrm{CA}-\mathrm{CR}+\mathrm{OI}$ & 35 & --- & $0(0)$ & & & --- \\
\hline & $\mathrm{IA}-\mathrm{CA}-\mathrm{Col}$ & 35 & --- & $0(0)$ & $\begin{array}{c}2[0.9034 \pm 0.0079] \\
(0.8978,0.9089)\end{array}$ & --- & $\begin{array}{c}33[0.968 \pm 0.065] \\
(0.7379-1.0000)\end{array}$ \\
\hline & $\mathrm{IA}-\mathrm{CR}+\mathrm{OI}-\mathrm{Col}$ & 35 & --- & $0(0)$ & -- & $\begin{array}{l}5[0.580 \pm 0.071] \\
(0.5079-0.6800)\end{array}$ & $\begin{array}{c}30[0.784 \pm 0.133] \\
(0.5326-0.9736)\end{array}$ \\
\hline & $\mathrm{CA}-\mathrm{CR}+\mathrm{OI}-\mathrm{Col}$ & 35 & --- & --- & $\begin{array}{c}2[0.729 \pm 0.169] \\
(0.6099,0.8489)\end{array}$ & $\begin{array}{l}3[0.563 \pm 0.063] \\
(0.5112-0.6337)\end{array}$ & $\begin{array}{c}30[0.818 \pm 0.154] \\
(0.4593-0.9855)\end{array}$ \\
\hline $\begin{array}{l}\text { Illustration study } 2 . \\
\text { Diagrams based on } \\
\text { log-ratios of major } \\
\text { elements }\end{array}$ & $\begin{array}{c}\{\Sigma n\}\left\{\sum \text { prob }\right\} \\
{[\% \text { prob }]}\end{array}$ & 175 & $\begin{array}{c}\{2\} \\
\{1.4128\} \\
{[---]}\end{array}$ & $\begin{array}{c}\{0\}\{0\} \\
{[0 \%]}\end{array}$ & $\begin{array}{c}\{8\}\{6.2436\} \\
{[5.2 \%]}\end{array}$ & $\begin{array}{c}\{43\}\{36.1587\} \\
{[24.3 \%]}\end{array}$ & $\begin{array}{c}\{122\}\{104.8148\} \\
{[70.5 \%]}\end{array}$ \\
\hline \multirow{5}{*}{$\begin{array}{l}\text { Acid; Verma et al. } \\
(2013) \text {; log-ratios of } \\
\text { major and immobile } \\
\text { trace elements }\end{array}$} & $\mathrm{IA}+\mathrm{CA}-\mathrm{CR}+\mathrm{OI}-\mathrm{Col}$ & 33 & $\begin{array}{l}2[0.508 \pm 0.109] \\
(0.4311,0.5847)\end{array}$ & --- & --- & $\begin{array}{c}13[0.689 \pm 0.137] \\
(0.5049-0.8972)\end{array}$ & $\begin{array}{c}18[0.634 \pm 0.075] \\
(0.4938-0.7936)\end{array}$ \\
\hline & $\mathrm{IA}-\mathrm{CA}-\mathrm{CR}+\mathrm{OI}$ & 33 & --- & $1(0.7142)$ & $\begin{array}{l}4[0.612 \pm 0.086] \\
(0.5134-0.6948)\end{array}$ & $\begin{array}{c}28[0.914 \pm 0.099] \\
(0.6691-0.9962)\end{array}$ & --- \\
\hline & $\mathrm{IA}-\mathrm{CA}-\mathrm{Col}$ & 33 & --- & $1(0.7177)$ & $1(0.6637)$ & 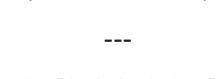 & $\begin{array}{c}31[0.875 \pm 0.128] \\
(0.4931-0.9966)\end{array}$ \\
\hline & $\mathrm{IA}-\mathrm{CR}+\mathrm{OI}-\mathrm{Col}$ & 33 & --- & $1(0.7359)$ & --- & $\begin{array}{c}15[0.658 \pm 0.115] \\
(0.4960-0.8476)\end{array}$ & $\begin{array}{l}17[0.617 \pm 0.078] \\
(0.4585-0.7436)\end{array}$ \\
\hline & $\mathrm{CA}-\mathrm{CR}+\mathrm{OI}-\mathrm{Col}$ & 33 & --- & --- & $\begin{array}{c}2[0.5496 \pm 0.0417] \\
(0.5201,0.5791) \\
\end{array}$ & $\begin{array}{l}15[0.656 \pm 0.147] \\
(0.5022-0.9147)\end{array}$ & $\begin{array}{c}16[0.588 \pm 0.106] \\
(0.4486-0.7863)\end{array}$ \\
\hline $\begin{array}{l}\text { Illustration study } 2 . \\
\text { Diagrams based on } \\
\text { log-ratios of major } \\
\text { and immobile trace } \\
\text { elements }\end{array}$ & 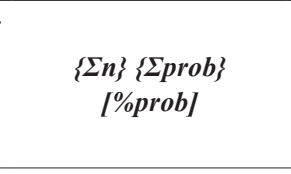 & 165 & $\begin{array}{c}\{2\}\{1.0158\} \\
{[---]}\end{array}$ & $\begin{array}{c}\{3\}\{2.1677\} \\
{[2.1 \%]}\end{array}$ & $\begin{array}{c}\{7\}\{4.2111\} \\
{[4.0 \%]}\end{array}$ & $\begin{array}{c}\{71\}\{54.2471\} \\
{[45.2 \%]}\end{array}$ & $\begin{array}{c}\{82\}\{58.4380\} \\
48.7 \%]\end{array}$ \\
\hline \multirow{5}{*}{$\begin{array}{l}\text { Acid; Verma et al. } \\
(2013) \text {; log-ratios } \\
\text { of immobile trace } \\
\text { elements }\end{array}$} & $\mathrm{IA}+\mathrm{CA}-\mathrm{CR}+\mathrm{OI}-\mathrm{Col}$ & 33 & $\begin{array}{l}6[0.592 \pm 0.165] \\
(0.4149-0.8859)\end{array}$ & --- & --- & $\begin{array}{l}5[0.776 \pm 0.183] \\
(0.5691-0.9802)\end{array}$ & $\begin{array}{c}22[0.758 \pm 0.133] \\
(0.5192-0.9352)\end{array}$ \\
\hline & IA-CA-CR + OI & 33 & --- & $0(0)$ & $\begin{array}{c}20[0.844 \pm 0.161] \\
(0.5273-0.9987)\end{array}$ & $\begin{array}{l}13[0.910 \pm 0.122] \\
(0.5838-1.0000)\end{array}$ & -- \\
\hline & IA-CA-Col & 33 & --- & $0(0)$ & $\begin{array}{l}6[0.748 \pm 0.079] \\
(0.6637-0.8685)\end{array}$ & -- & $\begin{array}{c}27[0.823 \pm 0.141] \\
(0.5069-0.9901)\end{array}$ \\
\hline & $\mathrm{IA}-\mathrm{CR}+\mathrm{OI}-\mathrm{Col}$ & 33 & --- & $0(0)$ & --- & $\begin{array}{l}6[0.807 \pm 0.192] \\
(0.5150-0.9834)\end{array}$ & $\begin{array}{c}27[0.889 \pm 0.119] \\
(0.5735-0.9997)\end{array}$ \\
\hline & $\mathrm{CA}-\mathrm{CR}+\mathrm{OI}-\mathrm{Col}$ & 33 & --- & --- & $\begin{array}{c}9[0.660 \pm 0.132] \\
(0.4786-0.9497) \\
\end{array}$ & $\begin{array}{c}5[0.762 \pm 0.161] \\
(0.5758-0.9120) \\
\end{array}$ & $\begin{array}{c}19[0.760 \pm 0.128] \\
(0.4740-0.9024) \\
\end{array}$ \\
\hline $\begin{array}{l}\text { Illustration study } 2 . \\
\text { Diagrams based on } \\
\text { log-ratios of immo- } \\
\text { bile trace elements }\end{array}$ & $\begin{array}{c}\{\Sigma \mathrm{n}\}\left\{\sum \text { prob }\right\} \\
{[\% \text { prob }]}\end{array}$ & 165 & $\begin{aligned}\{6\} & \{3.5490\} \\
& {[---] }\end{aligned}$ & $\begin{array}{c}\{0\}\{0\} \\
{[0 \%]}\end{array}$ & $\begin{array}{c}\{35\}\{27.3014\} \\
{[23.3 \%]}\end{array}$ & $\begin{array}{c}\{29\}\{24.3650\} \\
{[18.4 \%]}\end{array}$ & $\begin{array}{c}\{95\}\{77.3447\} \\
{[58.3 \%]}\end{array}$ \\
\hline
\end{tabular}


roughly equally distributed in the collision, within-plate, and continental-arc setting (Tab. 3).

Thirty-five samples of acid rocks were used in all four diagram sets (Tab. 4). The two major-element based diagram sets have indicated a collisional setting with high total probability values of c. $75 \%$ and $70 \%$ (Tab. 4). The major- and immobile trace-element based diagram set has been more consistent with a transitional collision to within-plate setting with roughly similar total percent probability values of about $49 \%$ and $45 \%$, but the final immobile trace-element based diagram set indicated a collision setting with a total percent probability value of c. $58 \%$ (Tab. 4).

\subsection{Comparison with the previous studies}

Janoušek et al. (2000a, b) concluded that assimilation and fractional crystallization was the dominant petrogenetic process with the magma mixing being responsible for only local influence in the origin and evolution of the calc-alkaline magmas of the CBP. Janoušek et al. (2010) suggested that mantle-derived magmas provided sufficient heat for crustal anatexis to generate the Blatná suite of the CBP. The complex tectonic evolution of the region was difficult to be inferred beyond doubt. Conventional tectonic discrimination diagrams were not used by the original authors (Janoušek et al. 2000a, b, 2004, 2010; Žák K. et al. 2014) even though multielement plots were employed for this purpose and continental-arc setting was proposed. Our application of multidimensional diagrams, however, indicated a transitional continental arc to collision tectonic setting but the influence of petrogenetic processes must be taken into account in this inference.

Ulrych et al. (2004, 2006) suggested that assimilation and fractional crystallization processes in shallow magma chambers were responsible for the origin of the PermoCarboniferous volcanism in the Bohemian Massif. They used the $\mathrm{Ta} / \mathrm{Yb}-\mathrm{Th} / \mathrm{Yb}$ diagram of Pearce (1983) in which their samples plotted in the active continental margin field. Laurent et al. (2014) opined that the Žulová Pluton was probably related to the extensional reactivation of pre-existing lithospheric discontinuities. These authors used two diagrams of Pearce et al. (1984). In the $\mathrm{Y}-\mathrm{Nb}$ diagram, their samples plotted mostly in the overlap region of within-plate and ocean-ridge granite fields, with some overlap to the adjacent igneous-arc/syn-collisional field. In the other diagram $(\mathrm{Y}+\mathrm{Nb}-\mathrm{Rb})$, the samples indicated a transitional volcanic arc to within-plate setting. Laurent et al. (2014) also used two ternary diagrams. In the Hf- $\mathrm{Rb} / 30-3 \times \mathrm{Ta}$ diagram of Harris et al. (1986), three samples plotted in the late or post-collisional field and two in the volcanic-arc setting. The Th-Hf/3-Nb/16 diagram of Wood (1980) was more consistent with an arc setting of the basic rocks. Our multidimensional diagrams indicate a collision or a transitional collision to withinplate setting.

\subsection{Advantages and weaknesses of the new diagrams}

The main advantages of the new multidimensional diagrams are that they take care of the three basic problems of the older diagrams (Agrawal and Verma 2007). These problems and their solutions are as follows: (i) constant sum (or closure) problem associated with all compositional data was solved by the log-ratio transformation techniques; (ii) subjective boundaries for the tectonic fields to be discriminated were replaced by probabilitybased boundaries and (iii) inadequate sampling was overcome by establishing representative worldwide databases used in the proposal of these diagrams. With these improvements, the new diagrams work more satisfactorily than the conventional bivariate or ternary diagrams (Verma 2015a). The multidimensional nature and log-transformation also render these diagrams less susceptible to post-emplacement changes (Verma and Verma 2013; Verma et al. 2013). The computer programs TecD (Verma and Rivera-Gómez 2013) and TecDIA (this work) would facilitate the use of all newly designed diagrams for igneous rocks.

The major drawback of the multidimensional diagrams is that they do not take into account the indications from petrogenetic modelling. Thus, the different rock or magma types (basic, intermediate, and acid) may provide different indications for the tectonic setting because they may have totally different origin of their parental magmas. Finally, the application to a given area may also be subject to the availability of sufficiently large number of samples with complete geochemical data.

Therefore, additional considerations of petrogenetic processes should be helpful for better understanding the tectonic implications from multidimensional diagrams as recently discussed by Verma $(2015 b$, c) for the eastern and central parts of the Mexican Volcanic Belt and the Central American Volcanic Arc. These and other shortcomings of these multidimensional diagrams have also been recently summarized by Verma et al. (2015a, b). Our future work will involve combining the petrogenetic inferences with the multidimensional technques.

\section{Conclusions}

A new computer program TecDIA for the application of 35 multidimensional diagrams for intermediate and acid magmatic rocks has been briefly described. TecDIA estimates the number of samples plotting in different tectonic fields and computes the respective probabilities. 
As an option, it provides the corresponding graphics for the visualization of the data. This programs yields two different types of reports in the Excel format, one of them ready to "copy and paste" in tables for publication. The use of this program has been successfully illustrated by two examples of igneous suites of the Variscan Bohemian Massif.

Acknowledgements. This work was partly supported by DGAPA-PAPIIT project IN104813. SKV thanks to the Fundação de Amparo à Pesquisa do Estado de São Paulo (FAPESP), Brazil, for grants 2012/07243-3 and 12/15824-6. We are grateful to the three reviewers (B. Bonin, J.-F.Moyen, and anonymous) and the editor (V. Janoušek) for providing us with numerous comments and suggestions to improve our presentation.

Electronic supplementary material. Four tables, one figure and Readme file for this paper are available online at the Journal web site (http://dx.doi.org/10.3190/ jgeosci.201).

\section{References}

Agrawal S (1999) Geochemical discrimination diagrams: a simple way of replacing eye-fitted boundaries with probability based classifier surfaces. J Geol Soc India 54: 335-346

Agrawal S, Verma SP (2007) Comment on "Tectonic classification of basalts with classification trees" by Pieter Vermeesch (2006). Geochim Cosmochim Acta 71: 3388-3390

Agrawal S, Guevara M, Verma SP (2004) Discriminant analysis applied to establish major-element field boundaries for tectonic varieties of basic rocks. Int Geol Rev 46: 575-594

Agrawal S, Guevara M, Verma SP (2008) Tectonic discrimination of basic and ultrabasic rocks through logtransformed ratios of immobile trace elements. Int Geol Rev 50: 1057-1079

Aitchison J (1981) A new approach to null correlations of proportions. Math Geol 13: 175-189

Aitchison J (1984) The statistical analysis of geochemical compositions. Math Geol 16: 531-564

Aitchison J (1986) The Statistical Analysis of Compositional Data. Chapman and Hall, London, UK, pp 1-416

Aitchison J (1999) Logratios and natural laws in compositional data analysis. Math Geol 31: 563-580

BAILEY JC (1981) Geochemical criteria for a refined tectonic discrimination of orogenic andesites. Chem Geol 32: $139-154$

Buccianti A (2013). Is compositional data analysis a way to see beyond the illusion? Comput Geosci 50: 165-173
ButLer JC, Woronow A (1986) Discrimination among tectonic settings using trace element abundances of basalts. J Geophys Res 91: 10289-10300

Cabanis B, Lecolle M (1989) Le diagramme La/10 $\mathrm{Y} / 15-\mathrm{Nb} / 8$ : un outil pour la discrimination des séries volcaniques et la mise en évidence des processus de mélange et/ou de contamination crustale. C R Acad Sci Paris 309: 2023-2029

Chayes F (1960) On correlation between variables of constant sum. J Geophys Res 65: 4185-4193

CHAYES F (1971) Ratio correlation. A manual for students of petrology and geochemistry. The University of Chicago Press, Chicago and London, pp 1-99

Egozcue JJ, Pawlowsky-Glahn V, Mateu-Figueras G, BarCELÓ-VIDAL C (2003) Isometric logratio transformations for compositional data analysis. Math Geol 35: 279-300

Gorton MP, SchandL ES (2000) From continents to island arcs: a geochemical index of tectonic setting for arcrelated and within-plate felsic to intermediate volcanic rocks. Canad Mineral 38: 1065-1073

Harris NBW, Pearce JA, Tindle AG (1986) Geochemical characteristics of collision-zone magmatism. In COWARD MP, Alison C (eds) Collision Tectonics. Geological Society of London Special Publications 19: 67-81

Janoušek V, Bowes DR, Rogers G, Farrow CM, Jelínek E (2000a) Modelling diverse processes in the petrogenesis of a composite batholith: the Central Bohemian Pluton, Central European Hercynides. J Petrol 41: 511-543

Janoušek V, Bowes DR, Braithwaite CJR, Rogers G (2000b) Microstructural and mineralogical evidence for limited involvement of magma mixing in the petrogenesis of a Hercynian high-K calc-alkaline intrusion: the Kozárovice granodiorite, Central Bohemian Pluton, Czech Republic. Trans Roy Soc Edinb, Earth Sci 91: $15-26$

Janoušek V, Braithwaite CJR, Bowes DR, Gerdes A (2004) Magma-mixing in the genesis of Hercynian calc-alkaline granitoids: an integrated petrographic and geochemical study of the Sázava intrusion, Central Bohemian Pluton, Czech Republic. Lithos 78: 67-99

JANOUŠEK V, WIEGAND BA, ŽÁ J (2010) Dating the onset of Variscan crustal exhumation in the core of the Bohemian Massif: new $\mathrm{U}-\mathrm{Pb}$ single zircon ages from the high-K calc-alkaline granodiorites of the Blatná suite, Central Bohemian Plutonic Complex. J Geol Soc, London 167: 347-360

Laurent A, Janoušek V, Magna T, Schulmann K, Míková J (2014) Petrogenesis and geochronology of a postorogenic calc-alkaline magmatic association: the Žulová Pluton, Bohemian Massif. J Geosci 59: 415-440

Le Bas MJ, Le Maitre RW, Streckeisen A, Zanettin B (1986) A chemical classification of volcanic rocks based on the total alkali-silica diagram. J Petrol 27: 745-750 
Le MaitRe RW (1976) Some problems of the projection of chemical data into mineralogical classifications. Contrib Mineral Petrol 56: 181-189

Le Maitre RW, Streckeisen A, Zanettin B, Le Bas MJ, Bonin B, Bateman P, Bellieni G, Dudek A, Schmid R, Sørensen H, Woolley AR (2002) Igneous rocks. A Classification and Glossary of Terms: Recommendations of the International Union of Geological Sciences Subcommission of the Systematics of Igneous Rocks. Second ed., Cambridge University Press, Cambridge, pp 1-236

McDonough WF, Sun SS (1995) The composition of the Earth. Chem Geol 120: 223-253

MeschedE M (1986) A method of discriminating between different types of mid-ocean ridge basalts and continental tholeiites with the $\mathrm{Nb}-\mathrm{Zr}-\mathrm{Y}$ diagram. Chem Geol 56: 207-218

MiddLemost EAK (1989) Iron oxidation ratios, norms and the classification of volcanic rocks. Chem Geol 77: 19-26

Mullen ED (1983) $\mathrm{MnO} / \mathrm{TiO}_{2} / \mathrm{P}_{2} \mathrm{O}_{5}$ : a minor element discrimination for basaltic rocks of oceanic environments and its implications for petrogenesis. Earth Planet Sci Lett 62: 53-62

Pandarinath K (2014) Testing of the recently developed tectonomagmatic discrimination diagrams from hydrothermally altered igneous rocks of 7 geothermal fields. Turkish J Earth Sci 23: 412-426

Pawlowsky-Glahn V, Egozcue JJ (2006) Compositional data and their analysis: an introduction. In: Buccianti A, Mateu-Figueras G, Pawlowsky-Glahn V (eds) Compositional Data Analysis in the Geosciences: From Theory to Practice. Geological Society of London Special Publications 264: $1-10$

Pearce JA (1982) Trace element characteristics of lavas from destructive plate boundaries. In: THORPE RS (ed) Andesites. John Wiley \& Sons, Chichester, pp 525-548

Pearce JA (1983) The role of sub-continental lithosphere in magma genesis at destructive plate margins. In: Hawkesworth CJ, Norry MJ (eds) Continental Basalts and Mantle Xenoliths. Shiva, Nantwich, pp 230-249

Pearce JA, Cann JR (1971) Ophiolite origin investigated by discriminant analysis using Ti, $\mathrm{Zr}$ and $\mathrm{Y}$. Earth Planet Sci Lett 12: 339-349

Pearce JA, Cann JR (1973) Tectonic setting of basic volcanic rocks determined using trace element analyses. Earth Planet Sci Lett 19: 290-300

Pearce JA, Norry MJ (1979) Petrogenetic implications of $\mathrm{Ti}, \mathrm{Zr}, \mathrm{Y}$, and $\mathrm{Nb}$ variations in volcanic rocks. Contrib Mineral Petrol 69: 33-47

Pearce JA, Harris NBW, Tindle AG (1984) Trace element discrimination diagrams for the tectonic interpretation of granitic rocks. J Petrol 25: 956-983

Pearson K (1897) Mathematical contribution to the theory of evolution. On a form of spurious correlation which may arise when indices are used in the measurement of organs. Proc Royal Soc London 60: 489-502
Rivera-Gómez MA, Verma SP (in press) Evaluation of 55 multidimensional tectonomagmatic discrimination diagrams from fresh and altered rocks. Geol Carpath

RoLLINSON HR (1993) Using Geochemical Data: Evaluation, Presentation, Interpretation. Longman, London, pp 1-344

Schulmann K, Lexa O, Janoušek V, Lardeaux JM, Edel JB (2014) Anatomy of a diffuse cryptic suture zone: an example from the Bohemian Massif, European Variscides. Geology 42: 275-278

Shervais JW (1982) Ti-V plots and the petrogenesis of modern and ophiolitic lavas. Earth Planet Sci Lett 59: $101-118$

SHETH HC (2008). Do major oxide tectonic discrimination diagrams work? Evaluating new log-ratio and discriminant-analysis-based diagrams with Indian Ocean mafic volcanics and Asian ophiolites. Terra Nova 20: 229-236.

Sun SS, McDonough WF (1989) Chemical and isotopic systematics of oceanic basalts: implications for mantle composition and processes. In: Saunders AD, Norry MJ (eds) Magmatism in the Ocean Basins. Geological Society of London Special Publications 42: 313-345

Ulrych J, Fediuk F, Lang M, Martinec P (2004) Late Paleozoic volcanic rocks of the Intra-Sudetic Basin, Bohemian Massif: petrological and geochemical characteristics. Chem Erde 64: 127-153.

Ulrych J, Pešek J, ŠtěpánKová-Svobodová J, Bosák P, LLOYd FE, von SECKendorfF V, LANG M, NovÁk JK (2006) Permo-Carboniferous volcanism in late Variscan continental basins of the Bohemian Massif (Czech Republic): geochemical characteristic. Chem Erde 66: 37-56.

Velikoslavinsky SD, Krylov DP (2014) Geochemical discrimination of basalts formed in major geodynamic settings. Geotectonics 48: 427-439

VERMA SP (2010) Statistical evaluation of bivariate, ternary and discriminant function tectonomagmatic discrimination diagrams. Turkish J Earth Sci 19: 185-238

Verma SP (2012) Application of multi-dimensional discrimination diagrams and probability calculations to acid rocks from Portugal and Spain. Comunic Geol 99: 79-93

VERMA SP (2015a) Monte Carlo comparison of conventional ternary diagrams with new log-ratio bivariate diagrams and an example of tectonic discrimination. Geochem $\mathrm{J}$ 49: $393-412$

VERMA SP (2015b) Origin, evolution, and tectonic setting of the eastern part of the Mexican Volcanic Belt and comparison with the Central American Volcanic Arc from conventional multielement normalized and new multidimensional discrimination diagrams and discordancy and significance tests. Turkish J Earth Sci 24: 111-164

Verma SP (2015c) Present state of knowledge and new geochemical constraints on the central part of the Mexican Volcanic Belt and comparison with the Central American Volcanic Arc in terms of near and far trench magmas. Turkish J Earth Sci 24: 399-460 
Verma SP, Agrawal S (2011) New tectonic discrimination diagrams for basic and ultrabasic volcanic rocks through log-transformed ratios of high field strength elements and implications for petrogenetic processes. Rev Mex Cienc Geol 28: 24-44

Verma SP, Rivera-Gómez MA (2013) Computer programs for the classification and nomenclature of igneous rocks. Episodes 36: 115-124

Verma SP, Verma SK (2013) First 15 probability-based multi-dimensional discrimination diagrams for intermediate magmas and their robustness against postemplacement compositional changes and petrogenetic processes. Turkish J Earth Sci 22: 931-995

Verma SP, Torres-Alvarado IS, Sotelo-Rodríguez ZT (2002) SINCLAS: standard igneous norm and volcanic rock classification system. Comput Geosci 28: 711-715

Verma SP, Guevara M, Agrawal S (2006) Discriminating four tectonic settings: five new geochemical diagrams for basic and ultrabasic volcanic rocks based on log-ratio transformation of major-element data. J Earth Syst Sci 115: 485-528

Verma SK, Pandarinath K, Verma SP (2012) Statistical evaluation of tectonomagmatic discrimination diagrams for granitic rocks and proposal of new discriminantfunction-based multi-dimensional diagrams for acid rocks. Int Geol Rev 54: 325-347

Verma SP, Pandarinath K, Verma SK, Agrawal S (2013) Fifteen new discriminant-function-based multi-dimensional robust diagrams for acid rocks and their application to Precambrian rocks. Lithos 168-169: 113-123

Verma SP, Verma SK, Oliveira EP (2015a) Application of 55 multi-dimensional tectonomagmatic discrimina- tion diagrams to Precambrian belts. Int Geol Rev 57: 1363-1386

Verma SK, Oliveira EP, Verma SP (2015b) Plate tectonic settings for Precambrian basic rocks from Brazil by multi-dimensional tectonomagmatic discrimination diagrams and their limitations. Int Geol Rev 57: 1566-1581

Winchester JA, The PACE TMR Network Team (2002) Palaeozoic amalgamation of Central Europe: new results from recent geological and geophysical investigations. Tectonophysics 360: 5-21

Wood DA (1980) The application of a Th-Hf-Ta diagram to problems of tectonomagmatic classification and to establishing the nature of crustal contamination of basaltic lavas of the British Tertiary Volcanic Province. Earth Planet Sci Lett 50: 11-30

Ž́á J, Verner K, Janoušek V, Holub FV, Kachlík V, Finger F, Hajná J, Tomek F, Vondrovic L, Trubač J (2014) A plate-kinematic model for the assembly of the Bohemian Massif constrained by structural relationships around granitoid plutons. In: SchULmanN K, Martínez Catalán JR, Lardeaux JM, Janoušek V, OgGiano G (eds), The Variscan Orogeny: Extent, Timescale and the Formation of the European Crust. Geological Society of London Special Publications 405: 169-196

Žák K, SvojtKa M, Breiter K, Ackerman L, Zachariáš J, Pašava J, Veselovský F, Litochleb J, Ďurišová J, Haluzová E (2014) Padrt' Stock (Teplá-Barrandian Unit, Bohemian Massif): petrology, geochemistry, U$\mathrm{Pb}$ zircon dating of granodiorite, and $\mathrm{Re}-\mathrm{Os}$ age and origin of related molybdenite mineralization. J Geosci 59: $351-366$ 